IZA DP No. 8229

Teenage Pregnancies and Births in Germany: Patterns and Developments

Kamila Cygan-Rehm

Regina T. Riphahn

May 2014 


\title{
Teenage Pregnancies and Births in Germany: Patterns and Developments
}

\author{
Kamila Cygan-Rehm \\ University of Erlangen-Nuremberg \\ Regina T. Riphahn \\ University of Erlangen-Nuremberg \\ and IZA
}

Discussion Paper No. 8229

May 2014

IZA
P.O. Box 7240
53072 Bonn
Germany

Phone: +49-228-3894-0

Fax: +49-228-3894-180

E-mail: iza@iza.org

\begin{abstract}
Any opinions expressed here are those of the author(s) and not those of IZA. Research published in this series may include views on policy, but the institute itself takes no institutional policy positions. The IZA research network is committed to the IZA Guiding Principles of Research Integrity.

The Institute for the Study of Labor (IZA) in Bonn is a local and virtual international research center and a place of communication between science, politics and business. IZA is an independent nonprofit organization supported by Deutsche Post Foundation. The center is associated with the University of Bonn and offers a stimulating research environment through its international network, workshops and conferences, data service, project support, research visits and doctoral program. IZA engages in (i) original and internationally competitive research in all fields of labor economics, (ii) development of policy concepts, and (iii) dissemination of research results and concepts to the interested public.
\end{abstract}

IZA Discussion Papers often represent preliminary work and are circulated to encourage discussion. Citation of such a paper should account for its provisional character. A revised version may be available directly from the author. 
IZA Discussion Paper No. 8229

May 2014

\section{ABSTRACT}

\section{Teenage Pregnancies and Births in Germany: Patterns and Developments}

We study the development of teenage fertility in East and West Germany using data from the German Socioeconomic Panel (SOEP) and from the German Mikrozensus. Following the international literature we derive hypotheses on the patterns of teenage fertility and test whether they are relevant in the German case. We find that teenage fertility is associated with teenage age and education, with the income of the teenager's family, with migration status, residence in East Germany, and aggregate unemployment. Our evidence supports countercyclical teenage fertility.

JEL Classification: J13, Z18, 100

Keywords: $\quad$ teenage fertility, abortion, unemployment, East and West Germany, population economics

Corresponding author:

Regina T. Riphahn

University Erlangen-Nuremberg

Economics Department

Lange Gasse 20

90403 Nuremberg

Germany

E-mail: regina.riphahn@wiso.uni-erlangen.de

* Forthcoming in: Applied Economics. We thank Miriam Mäder and Guido Heineck for very helpful and insightful comments. 


\section{Introduction}

We know that teen fertility can be detrimental for mother and child. Independent of whether teen motherhood is considered a problem in itself or merely the symptom of a (different) problem, it is important to understand the underlying mechanisms. The economic literature on teenage pregnancy and fertility, its causes, and consequences typically studies nations with high teen fertility rates, such as the United States or the United Kingdom. Compared to these countries, teen fertility in Germany has generally been lower. However, as East German teen fertility recently increased by 86 percent between 1995 and 2010 and West German teen fertility fell by more than half between 1992 and 2011 it is of interest to study the patterns and driving forces behind the different teenage fertility patterns and their time trends in East and West Germany.

From an international perspective, evidence from a European country with modest and in part even declining teen fertility rates may provide a case study or benchmark that generates new and interesting insights. Possibly, accepted mechanisms that explain patterns of high fertility are not valid across heterogeneous institutional frameworks. From a national perspective with the impending challenges of demographic aging and a shrinking labor force, it is all the more important to attend to teenage fertility particularly as we know very little about its patterns and determinants. Recently, Keller (2011) studied the consequences of teenage motherhood in Germany and showed that it is associated with low educational attainment and reduced subsequent marital stability. ${ }^{1}$ New studies based on developments over time and heterogeneity across states in the United States (Kearney and Levine 2012a) point to the relevance of the welfare system and to social marginalization as important determinants of early fertility. We investigate whether the heterogeneity of regional and ethnic circumstances yields similar patterns for Germany.

$1 \quad$ For a study on long-run effects of early life adversities see Blomeyer et al. (2013). 
Determinants and patterns of teenage fertility in Germany have not been studied before. The extant evidence is limited to literature that uses qualitative methods and focuses on how to best support pregnant teenagers (e.g., Franz and Busch 2004, Friedrich and Remberg 2005). We apply data from two large datasets, the German Socioeconomic Panel (SOEP) and the German Mikrozensus for the time since 1984 to investigate the incidence and correlation patterns of teen births in Germany. While we do not have detailed information on the individual processes along the fertility tree (e.g., contraception, sexual behavior, abortion), which is available in other countries, this is the first empirical study on the incidence of German teen fertility from an economic perspective. We describe the relevant institutional background and apply both, official population statistics and survey data on teen fertility.

We find that survey data somewhat underestimate teen fertility, that teen and parent characteristics affect the propensity of teen child bearing, and that first generation immigrants and teens in low income households are at a higher risk. Teen births are more frequent in East than in West Germany which appears to be connected to aggregate unemployment. The falling teen fertility rate in West Germany appears to be associated with the population share of immigrants and with economic indicators such as unemployment and GDP growth.

In the next section, we describe teen fertility trends in Germany. Also, we describe the relevant institutional background with respect to contraceptive availability, abortion regulations, and welfare benefits. Section three reviews the literature and presents our hypotheses. After a description of our data in section four, we present results and draw conclusions in sections five and six.

\section{Descriptive Evidence and Institutional Background}

\subsection{Teen Fertility in Germany over Time and in International Comparison}

By international comparison, teen fertility rates in Germany are low. Table 1 presents the development of adolescent fertility per 1,000 females aged 15-19 since 1998 in a selection 
of countries. Teen fertility has been declining in most countries. As of 2009 German teen fertility (7.2) is below the European average (12.2) and far below the figures observed for the United States (32.6) or for the United Kingdom (22.2).

Figure 1.1 shows the development of teen fertility in Germany over time. The time trends differ substantially between East and West Germany. While West German teen birth rates trend downwards since the early 1990s, the East German gradient is positive since the mid 1990s. As of 2010 we observe about 6 and 14 births in 1,000 teenagers in West and East Germany, respectively. Figure 1.2 presents total fertility rates for women aged 15-49 separately for East and West Germany since 1990. Both, overall and teen fertility in East Germany dropped substantially and below West German fertility levels in the early 1990s, after unification. Whereas West German overall fertility remained about constant over time West German teen birth rates declined. Hence, East German teenage fertility passed West German levels much earlier than East German overall fertility.

\subsection{Abortions in Germany over Time and in International Comparison}

Changes in birth rates can be affected by abortion behavior. Figure 2 presents the development of the share of abortions in all teenage pregnancies in several countries. The ratios for Germany, Spain, Italy, and the U.K. are quite similar and indicate that about half of all adolescent pregnancies are resolved by abortion. In France the ratios (observable through 2003) were higher and in the U.S. they reached only 30 percent.

The institutional setting for abortions has been harmonized between East and West Germany in 1996. Since then German law permits abortions up to the 12th week of a pregnancy if the woman received consultation and passed a subsequent waiting period of three days. After the 12th week of the pregnancy abortions are possible without time limits if there is a risk to the life and health of the mother (medical indication) and if the pregnancy is the result of a crime (criminal indication). The expenses for abortions based on the two 
indications are typically borne by health insurances whereas abortions following a consultation are to be paid privately. However, in particular cases expenses can be covered by the health insurance system.

Figure 3 presents abortion rates, i.e. the number of abortions per 1,000 women, in East and West Germany over time. Figure 3.1 shows that the abortion rates among adolescent females increased in East Germany over time and now reach about 8 in 1,000 women per year. In contrast, abortion rates recently declined in West Germany and are now at about 5 in 1,000. Figure 3.2 shows that abortion rates for women of all ages are about constant and higher in East than in West Germany, at 10 and 8 per 1,000 women. Regional patterns differ again when we relate abortions to the number of pregnancies. Figure 3.3 indicates that the share of abortions in all teen pregnancies (i.e., in the sum of births and abortions) is higher in West Germany (45 percent) than in East Germany (36 percent). Teen birth rates in East and West would continue to differ substantially even if abortion behaviors were identical. ${ }^{2}$ For females of all ages the rate of abortions in all pregnancies in 2010 amounted to 16.5 percent; these numbers are higher in the East $(21.5$ percent $)$ than in the West (15.1 percent). ${ }^{3}$ Overall, the difference in East and West German teen birth outcomes are due to differences in the incidence of pregnancy rather than to heterogeneity in abortion behaviors.

\subsection{Access to Contraceptives for Teenagers}

Generally, all contraceptives are available for purchase. The pill can only be obtained at pharmacies if a physician has ordered it for an individual. For females below age 14, parents have to consent to its use, for females aged 14 or 15 the physician decides whether or not parents have to consent, and for those aged 16 and above the parents have no right to be

2 For example, in 2010 we observe 14 births and 8 abortions per 1,000 teens in East and 6 births and 5 abortions per 1,000 teens in West Germany. If West Germans abort 36 percent of the pregnancies as East Germans do, birth rates would increase from 6 to 7. If East Germans abort 45 percent of all pregnancies, birth rates would fall from 14 to 12 in 1,000 teens.

The figures for West Germany exclude the city states Berlin, Bremen, and Hamburg. 
informed. In addition, emergency birth control ('morning after pill') can be obtained after a medical consultation and its provision does not require parental consent.

Overall, there is little information on contraceptive use by German teenagers. Recently, BZgA (2010) conducted a survey among about 6,000 14-17 years olds on contraceptive use and reported that the incidence of no contraception at first intercourse is higher in East than in West Germany, particularly among males. ${ }^{4}$

\subsection{The Welfare System and its Incentives}

The literature on teen fertility broadly discusses the effect of financial incentives inherent in public transfers and the welfare system. ${ }^{5}$ In Germany, welfare state institutions aim at securing a dignified life for families with children. For example, the replacement rate of unemployment insurance benefits increases from 60 to 67 percent of the last net income if minor children are in the household of the unemployed. Generally, parents receive a monthly child benefit for every child. It amounts to 184 Euro for the first child, increases with parity, and reaches 215 Euro per month for fourth and higher order children (as of 2010).

Of particular relevance are means tested benefits for single parents. The German welfare state supports individuals if they are in means-tested need. Since pregnant women have higher financial needs the amount transferred increases by up to 17 percent during pregnancy and increases further after child birth. Thus, whereas a single person can claim up to 364 Euro per month in addition to housing, heat, and health insurance, the amount increases by 215 Euro per month if there also is one child below age 6 to be cared for (as of 2012). With increasing age of the child the child benefit increases up to 287 Euro per month. Moreover, single parents are eligible for additional support of another 12 to 36 percent of the

$4 \quad$ In East Germany 18 percent of males did not use contraception at first intercourse, compared to 7 percent in West Germany. The differences among females are smaller with 10 percent in East and 8 percent in West Germany. In addition, East German females more often use risky methods of contraception (e.g., coitus interruptus) than West German females.

$5 \quad$ See e.g. Blank (1995), Miranne and Young (2002), Hao et al. (2007), Kearney and Levine (2012b), Levine (2002), Wolfe et al. (2001), Lundberg and Plotnick (1995), or Aassve (2003). 
child benefit. If teenage parents wish to live by themselves the welfare office can support them in leaving the parental home.

\subsection{Other Developments}

Four other issues are commonly discussed as background developments of teenage pregnancies: age at menarche, age at first sex, age at marriage, and the population share marrying at all. BZgA (2006) compares survey results for 1980 and 2005 and reports that age at menarche is now substantially earlier than 25 years ago. ${ }^{6}$ Also, they report that the share of youths with sexual experiences at a given age increased over time. ${ }^{7}$

In contrast, the age at first marriage in Germany has been rising steadily. It increased from 28.5 (men) and 26.1 (women) in 1991 to 33.2 (men) and 30.3 (women) in 2010. Overall, individuals marry later and less now than in the past (Emmerling 2012). As of 2011 only 54 percent of minors in East Germany live with married couples (down from 72 percent in 1996). These rates are substantially higher at 75 (2011) and 84 (1996) percent in West Germany.

\section{Determinants of Teenage Fertility: Literature and Hypotheses}

\subsection{Literature on factors and mechanisms}

Teenage fertility, pregnancy, and sexual behavior have been studied from various disciplinary perspectives. The literature is dominated by two broad themes, the incidence and causes of teenage fertility on the one hand and the effects on mother and child on the other. This section summarizes the literature on economic determinants of births to teen mothers. The studies distinguish the contribution of individual, parent, peer, and partner characteristics as micro factors from mechanisms that operate at the aggregate level. The latter include

$6 \quad$ The share of 14 year old females who had experienced their first menstruation had increased from 82 (1980) to 90 (2005) percent.

For example, the share of 17 year olds who had had sex increased from 56 / 38 percent (female / male) in 1980 to 73 / 66 percent in 2005. 
macroeconomic factors such as regional unemployment and growth as well as specific policies (e.g., availability of contraception, abortion, and welfare benefits).

The literature on the micro-level patterns of teenage fertility generally investigates whether the expected costs and benefits of a birth influence youth behaviors that may result in teen births. The studies model the utility of giving birth, consider the contribution of family and community background and of budget constraints reflecting household income.

In this framework, Lundberg and Plotnick (1995) estimate a nested logit model of pregnancy, abortion, and marriage outcomes. The authors consider a wide set of individual background indicators as well as state-level variables. They conclude that economic incentives matter for premarital childbearing. In addition, they find significant positive associations of welfare benefits with pre-marital births, of abortion availability with abortions, and of restrictions on contraceptives with pregnancies for white teenagers. Wolfe et al. (2001) pick up on economic incentives and study the relevance of individual income expectations for teen non-marital childbearing. The authors calculate the difference in the present value of predicted incomes with and without childbearing. They find that the predicted income loss after giving birth is negatively associated with the propensity to give birth. In a follow-up study, Wolfe et al. (2007) also find significant associations of teen childbearing with income and relationship expectations, maternal education, and neighborhood religiousness. Generally, the studies on the micro-level determinants of teen pregnancy emphasize the disadvantages related to background characteristics such as growing up with single parents, low education and poverty, and disadvantages for those of black race.

Influential studies on aggregate determinants of teenage fertility and on the role of labor market cyclicality are Levine (2001, 2002), Arkes and Klerman (2009), and recently Kearney and Levine (2012a). Economic theory does not provide clear predictions on the correlation between labor market tightness and youth fertility: a consumption good perspective on children predicts a pro-cyclical correlation (income effect), whereas an 
opportunity cost argument suggests that fertility increases in times of weak labor markets, i.e., counter-cyclically. Among teens, mechanisms such as the amount of unsupervised time, drug use, and career aspirations may be correlated with unemployment and may matter, as well.

Levine (2001) finds that employment opportunities are negatively associated with pregnancy risks, i.e., a counter-cyclical effect. In Levine (2002) he studies the 'fertility decision tree'. Controlling for state and year fixed effects he finds more pregnancies and births in times of low female unemployment, i.e., a pro-cyclical correlation for unmarried females. Similarly, Arkes and Klerman (2009) show mixed results. They find that aggregate unemployment is negatively associated with births among 18-20 years old females, but it is significantly positively correlated with births of 15-17 years old white females. The authors conclude that the choice of the unemployment rate (i.e., youth vs. aggregate) is influential and emphasize their finding of counter-cyclical teenage fertility. Also, Kearney and Levine (2012b) do not find clear correlations between teen fertility and state unemployment. They suggest that restricted access to contraception and high welfare benefits increase teenage birth rates; however, recent changes in welfare benefits and access to family planning explain only a small share of the decline in U.S. teen fertility.

In a different study, these authors (Kearney and Levine 2012a) discuss the role of marginalization and economic hopelessness for teen fertility. They confirm that poverty and a disadvantaged background increase the risk of teen births. Using interaction effects between individual poverty and aggregate indicators of the income distribution they point out that the risk of teen birth increases further if the teen lives in an environment of high inequality with "limited opportunities to advance socially and economically" (p.16). Teens' perceived opportunity costs of giving birth are lower if they find themselves in a hopeless situation.

This review yields a number of conclusions: first, the literature on teenage fertility is dominated by studies on the U.S.. While there are some contributions on developing 
countries, ${ }^{8}$ evidence for other developed countries is limited: Lupton and Kneale (2010) cite sociological studies on the U.K.. Some authors used a Norwegian school reform to identify fertility determinants (e.g., Black et al. 2008, Monstad et al. 2011). Among the few contributions that compare teen fertility across countries Jones et al. (1987) consider the availability of contraceptives and sex education as key to explain differences (similarly, Singh and Darroch 2000) while Darroch et al. (2001) stress that it is low teen contraceptive use that sets the U.S. apart from other developed countries. Second, the evidence on the micro-level determinants of teen fertility points to a set of key mechanisms. Besides ethnic differences, economic incentives appear to affect teen behaviors; also, household structure, parental education, income, and transfer dependence are associated with premarital teen births. Third, the literature on the macro-level determinants of teen fertility and on the relevance of the labor market is inconclusive. We find arguments and empirical evidence for pro- and for countercyclical labor market effects. Finally, there appears to be evidence for marginalization effects, where the impact of household poverty depends on the overall income distribution.

\subsection{Specific Hypotheses}

Following the literature, our analyses address two sets of hypotheses. In step one we investigate the relevance of individual and micro-level factors and in step two we study aggregate and regional patterns behind teen fertility in Germany. In a third step we investigate to what extent these covariates can explain the observed time trends in teenage fertility.

In the group of individual factors we hypothesize that teen fertility is connected to individual ability and educational attainment, which are related to expected life-time labor market outcomes (cf. Wolfe et al. 2001). We expect higher teen birth rates among those with less education. Second, we investigate the relevance of parental and household characteristics such as income, unemployment, and educational background for teen fertility. Our third set of

$8 \quad$ Examples are Baird et al. (2010), Kruger et al. (2009), and Cardoso and Verner (2008). 
hypotheses relates to U.S. evidence on heterogeneity in teenage fertility by ethnicity. We hypothesize that immigrants in Germany are subject to similar social and economic disadvantages as hispanic and black ethnic minorities in the U.S. and investigate the heterogeneity of teenage fertility by immigrant status. We provide separate results for Turkish immigrants in Germany because they represent the largest ethnic group, with particularly high fertility and early first births (e.g., Riphahn et al. 2013, Riphahn 2003).

In the step two our analyses we turn to aggregate patterns of teen fertility outcomes. Kearney and Levine (2012a) point to substantial regional differences in teenage fertility across U.S. states. Given macroeconomic and historic differences, we expect similar heterogeneity for East and West Germany. We investigate whether there are significant differences and how they might be explained. Next, we follow up on the literature on the cyclicality of teen fertility. Based on Arkes and Klerman (2009) we expect counter-cyclical correlations between the labor market and economic growth and teen fertility. Finally, we consider the marginalization hypothesis and test whether high regional income inequality enhances the effect of household income for teen fertility outcomes.

\section{Data and Descriptive Evidence}

\subsection{Data and Sample}

As, in contrast to the United States, teen births are rare events in Germany, it is challenging to obtain reliable empirical evidence on this issue. We take advantage of two complementary datasets: the German Socio-Economic Panel (SOEP) provides detailed information on its respondents (Wagner et al. 2007) and the German Mikrozensus offers information on large samples.

The SOEP contains retrospective biography information on childbearing for every female respondent aged 16 or older and on individual and family background prior to a first birth. From each survey year we select women aged 16-19 for whom we obtain a valid birth 
biography entry. ${ }^{9}$ We exclude 13 percent of female teenagers because their birth biography is missing, and another 0.02 and 0.04 percent because of missing data on migration background and education, respectively. ${ }^{10}$ Our SOEP sample uses the 1984-2010 surveys and includes 4,526 different teenage women. The main drawback of the SOEP is the small sample size: we observe on average 520 teenage women per survey year of whom about 1 percent give birth. We censor observations after a birth. Our final SOEP sample includes 14,046 teenage-year observations with 149 births. $^{11}$

In addition, we use the annual surveys of the German Mikrozensus (MZ), which collect information on one percent of German households. The scientific use files provide 70 percent of this sample. The survey is designed as a rotating panel: each responding household stays in the sample for up to four consecutive surveys. However, the data do not allow us to identify respondents over survey years; we pool cross-sectional data gathered in 1991, 1995, 1999, 2003, and 2007. The main shortcoming of the MZ is the lack of precise information on actual fertility and on individual characteristics prior to childbearing. Again, we select women aged between 16 and 19 in the survey year. Until 2004 the data were collected within one week in April or May, which is why we cannot observe births occurring in the remainder of the calendar year. ${ }^{12}$ To enhance the precision of our estimates, we use information as of any

9 A few births occur already prior to age 16. As we cannot observe these events in the data. we limit our analyses to the 16-19 age range throughout, which covers the vast majority of teen births: between 1991 and 2009 the share of births to mothers younger than 16 in all births to mothers aged below 20 varied between 2.5 and 4 percent (MPIDR 2012).

${ }_{10}$ This exclusion is nearly entirely related to the age restriction for collecting retrospective biography information on childbearing in the SOEP. The vast majority of the excluded women $(85 \%)$ would reach age 16 only in the respective survey year; their interview took place before their 16th birthday and they did not participate in the SOEP at any time later in life. The remaining $15 \%$ are relatively equally distributed across the considered ages: with $4 \%$ aged 17 years old, $5 \%$ are 18 , and $6 \%$ are 19 in the survey year. These women refused to provide their birth biography. Because the excluded women display a different age distribution compared to the analysis sample, their educational attainment also differs substantially: $96 \%$ were still in school at year $\mathrm{t}-1$, and for the remaining $4 \%$ the information on education is missing. The remaining variables do not indicate any major selection patterns. Importantly, our main results remain nearly unchanged if we include the observations with missing birth biography and treat them as non-mothers.

${ }_{11}$ We observe about two thirds of these females four times, i.e., at each age between 16 and 19; almost 4 percent provide one observation, 12 percent two, and 17 percent three repeated observations.

12 Subsequently, the Mikrozensus gathered information throughout the calendar year. 
cross survey year $\mathrm{t}$ not only to learn about those aged 16-19 in year $\mathrm{t}$, but also to gather information on women who were aged 16-19 in the previous year, $\mathrm{t}-1$, and who were surveyed at age 17-20 in year t. Thus, although we gather our data from five separate, cross-sectional survey years, our final MZ sample includes women aged 16-19 in both, these and the preceding years. ${ }^{13}$ The MZ sample provides information on 67,512 different teenage women, 25 percent of them enter the sample once and 75 percent enter twice based on the crosssectional information of specific survey years. Again, we censor observations after a first birth and obtain a final sample of 107,915 teenager-year observations of which 544 give birth.

The two samples differ in regional composition: the SOEP includes households from West German states since 1984 and adds information on East German households only since 1990. The MZ sample considers teenagers in East and West German states in all surveys.

\subsection{Dependent Variable}

Our dependent variable indicates whether a teenager gives her first birth in the observed calendar year. We calculate the difference in a women's year of birth and the year of birth of her oldest child to determine teenage motherhood. While the SOEP provides the birth year of a woman's first child, we rely on indirect information to determine a woman's age at first birth in the MZ because the MZ does not provide precise information on individual fertility. Specifically, we use information on household structure and on the family unit within a household; a family is defined to consist of at least one parent-child pair regardless of parental marital status and given that the child is unmarried (STBA 1995, 2006). We define teenage motherhood based on the woman's year of birth and the year of birth of the oldest

\footnotetext{
13 In principle, we could add observations from periods $\mathrm{t}-2$ and $\mathrm{t}-3$. However, we refrain from doing so because we only know the teens' characteristics as of year $t$; this should be increasingly misleading the further we go back in time. Similarly, as the birth took place prior to the survey, we do not use information on the teens' marital status at the time of the survey. Therefore we do not know whether a birth was pre-marital.
} 
child in her family. Unfortunately, we cannot identify stepchildren or adopted children and observe only children who live in their mother's household at the time of the interview.

Figure 4 displays the non-weighted share of SOEP and MZ observations with a first birth between the age 16 and 19 scaled to the number of births per 1,000 women. The measures differ from official teen fertility rates, which consider the age group 15-19 and do not focus on first births, only. For comparison, we also show official teen fertility rates reported by the German Federal Statistical Office. The plot reveals that the incidence of teen motherhood in the surveys does not perfectly match official teen birth rates. The incidence of teen motherhood in the MZ is too low by on average 20 percent, which may be due to measurement error. However, the trend is similar to that of the official teen birth rates. The teen fertility rates obtained with the SOEP generally follow official fertility rates, but display larger volatility due to the small number of observations.

\subsection{Explanatory Variables}

Our hypotheses address teen, parent, and household characteristics. Ideally, we would measure these characteristics prior to a birth. However, the MZ provides information only as of the time of the interview, i.e., after a potential birth, and does not contain information on parents. The SOEP allows us to measure several variables in the year prior to the survey, but we have to deal with missing information on these ex-ante characteristics. ${ }^{14}$

In each dataset we use seven categorical education indicators for teens. ${ }^{15}$ Only the SOEP data hold information on parental education where we use categorical indicators for the highest school and vocational degree reported by both parents. Generally, information on

\footnotetext{
14 We do not observe about 10 percent of the teenagers in our SOEP sample in a prior survey year. This share reaches 28 percent among teens that give birth. This does not affect our sample size as we generate missing value indicators where needed.

15 To minimize the number of missing values, we assume that teenagers who attend school in year $t$ were also enrolled in year $t-1$; nevertheless, the share of observations with missing education information in the SOEP reaches 23 and 2 percent among teenage mothers and non-mothers. We code missing value indicators for these observations to avoid losing observations.
} 
parental education is missing more frequently among teenagers who gave birth than among those who did not. We proxy the teenagers' economic situation by household net per capita income and an indicator of whether a household member receives unemployment benefits. The SOEP reports the average monthly household income after taxes in the previous year. The MZ collects information on net household income in the month prior to the interview. ${ }^{16}$ We define a comparable indicator of whether a member of the household receives unemployment benefits in both datasets. ${ }^{17}$

Both datasets offer information on teenagers' migration background. ${ }^{18}$ We generate for both surveys an indicator of first generation immigrant status, which is defined by place of birth in the SOEP and by the combination of foreign citizenship and individual migration history in the MZ.

Finally, we include regional characteristics. We use either 16 state indicators or a summary indicator for whether the individual lives in West Germany. To test whether teen fertility responds to cyclical changes in the economy, we use the annual (youth) state unemployment rate and GDP growth. In addition, we construct state-specific indicators for income inequality: using the full SOEP data, we describe the distribution of per capita (net real) household income by state and year. Our inequality indicators reflect the ratio of incomes at the 90th and 50th percentiles to that at the 10th percentile of the distribution. All time-varying indicators at the state level are lagged by one year.

Tables A.1 and A.2 in the appendix show descriptive statistics for the SOEP and the MZ samples, separately for teen mothers and non-mothers. The tables reveal a higher share of older teenagers among mothers than among non-mothers. Whereas more than fifty percent of

\footnotetext{
16 As the MZ variable is reported in intervals we use the mean of each income class. We impute incomes for 2 and 7 percent of observations in our SOEP and MZ samples with missing values using annual income measures. We use per capita monthly household income in 1,000 2005 Euros.

17 The indicator combines different types of unemployment benefits (Arbeitslosengeld, Arbeitslosenhilfe, ALG I, and ALG II) to achieve consistency over time.

18 While the SOEP allows us to distinguish non-migrants, first-generation immigrants (by country of origin), and second generation immigrants, the MZ surveys focus on citizenship and do not distinguish natives and naturalized immigrants.
} 
teen mothers are 19 years old at first birth, non-mothers are equally distributed across the considered ages. The low school enrollment among teen mothers (35 percent in the year preceding the birth) is striking and may be related to their age. Also, higher shares of teen mothers than non-mothers have dropped out of school.

The descriptive statistics reveal that teens from low income households and from households with unemployed members are more likely to be mothers. In addition, Table A.1 suggests that children of highly educated parents are less likely to become teen mothers. Despite different definitions of immigrant status, both datasets show similar patterns: first generation immigrants are overrepresented among teen mothers with a considerable share of Turkish women. Overall, descriptive statistics yield small but statistically significant differences in aggregate characteristics such as state GDP growth and income inequality between teen mothers and non-mothers.

\section{Multivariate Analyses}

We apply linear regressions to evaluate the correlation of micro-level and aggregate factors with the incidence of teen motherhood and to test the hypotheses set out in section 3.2. Our estimation model is as follows:

Teenage birth ${ }_{i t}=\beta_{0}+\beta_{1} X_{i t}+\beta_{2} P_{i}+\beta_{3} H_{i t}+\beta_{4} M_{i g}+\beta_{5} Z_{i t}+\beta_{6}$ Year FE $+e_{i t}$. Here, $\beta$ represents the vector of coefficients, $\mathrm{X}$ is a vector of teenage characteristics, $\mathrm{P}$ and $\mathrm{HH}$ represent parent and household characteristics. Mig reflects migration indicators, $\mathrm{Z}$ are regional characteristics, and Year FE stands for year fixed effects that are considered in all models. e is a random error term. We compute robust standard errors that are generally clustered at the individual level. In regressions that control for state level characteristics we cluster at the state-year-level.

\subsection{Step one: Micro-level factors}


Table 2 presents first evidence on the correlation between teen births, teen characteristics, and parental and household background. Columns 1 and 2 show the correlation between teen birth outcomes and age and education. In both samples, teen births are significantly more likely for older teens (age 16 being the reference). Similarly, the education patterns match across the two surveys: teens who are still attending school are less likely to give birth which may suggest that recent mothers tend to drop out of school. Compared to the reference group of teens with a lower secondary school degree (Hauptschule), those without a degree are significantly more likely to be a teen mother and those on higher educational pathways are significantly less likely to give birth. The evidence matches our first hypothesis laid out in section 3.2.

In the next columns, we additionally condition on parent and household background. The SOEP data provide information on parental education. The regression results in column 3 indicate that children of parents with unknown schooling are unlikely to be teenage mothers and those with unknown parental vocational degrees are likely to be teenage mothers. Part of this pattern may be explained by immigrants who have high teen birth rates and for whom the German equivalents of foreign parental vocational degrees may be unknown. Conditional on teenagers' own education, parental educational background does not yield precise results; however, jointly the coefficients of the parental education indicators are highly significant.

In columns 4 and 5 we add indicators of whether a member of the household receives unemployment benefits and of household net income per capita. As expected, we find a higher propensity for teen parenthood in low income households and in households with unemployed members. The estimates in both samples indicate a close correlation between poverty and teen fertility, which matches the hypotheses discussed in section 3.2.

Next, we consider heterogeneity in teen fertility outcomes between natives and immigrants. In columns 1 and 3 of Table 3 we add immigrant indicators: the coefficients are precisely estimated in both samples and indicate that birth rates among immigrant teens are 
higher by about 1.6 percentage points, which is substantial. In columns 2 and 4 we find particularly high teen birth rates among immigrants from Turkey. Immigrants from other countries of origin also have higher birth rates than natives; however, the difference is significant only in the MZ sample. ${ }^{19}$ The results confirm the expected heterogeneity in the incidence of teen fertility between natives and immigrants.

\subsection{Step two: Aggregate and regional patterns}

In step two of our analysis we concentrate on the association of aggregate and regional characteristics with teen fertility. First, we study the differences between East and West Germany, then we focus on teen fertility over the business cycle, and finally we investigate the marginalization hypothesis as proposed by Kearney and Levine (2012a).

As state level indicators are only fully available after 1991, we now restrict our analysis samples to the years after 1991. We start with an East-West comparison: despite the aggregate heterogeneity that we saw in Figure 1, conditional on year fixed effects the estimated teen fertility difference in Table 4 in (see columns 1 and 6) is statistically insignificant. However, within 'teen age-education-parental education' cells in SOEP data and 'teen age-education' cells in MZ data the incidence of teen births is significantly higher in East than in West Germany (see columns 4 and 8). This difference appears to be connected to household unemployment and poverty: once we control for these measures (see columns 5 and 9) the East-West gap loses precision again. ${ }^{20}$

Next, we extend the analysis of regional differences and consider additional state-level covariates. As baseline specifications, columns 1 and 4 of Table 5 show the results of the full model with a West Germany indicator, enhancing the specifications of Table 4 by immigrant

\footnotetext{
19 Also, we find that the correlation patterns in columns 4 and 5 of Table 2 differ significantly for immigrants and natives (results available upon request). Substantively, the patterns differ with respect to the age gradient of teen births, teen education, and household income.

20 In a fully interacted step one model a number of the correlation patterns differ for the two regional samples (results available upon request). In particular, the correlation between household income and teenage birth is more narrow in East than in West Germany.
} 
indicators. To investigate the cyclical character of German teen fertility and to learn more about the mechanisms behind the east-west differences, we follow Arkes and Klerman (2009) and add indicators for lagged state level youth unemployment in columns 2 and 5 of Table 5. We find positive correlations between teen fertility and youth unemployment, which are statistically significant in the MZ sample. The negative coefficient of the 'West Germany' indicator loses statistical significance once we control for regional unemployment. To test the robustness of the positive correlation of teen births with unemployment, we reestimated the models using aggregate instead of youth unemployment rates both with and without the East German sample (see columns 1-4 and 5-8 of Table A.3). All estimation results confirm the positive correlation between unemployment and teen fertility. When we add state fixed effects to the specifications in columns 2 and 5 of Table 5 (results not shown to save space) the youth unemployment coefficients remain positive, but are no longer statistically significant. ${ }^{21}$ The youth unemployment coefficient maintains its magnitude and turns out to be statistically significant at the five percent level, once we drop the household level indicators of unemployment benefit receipt and household income (results available upon request). As an additional robustness test we replaced aggregate unemployment by female unemployment; again, the results did not change. Overall, we obtain robust evidence in favor of a countercyclical correlation between teen fertility and youth unemployment: teen fertility is higher in years following periods of high unemployment. This suggests that the East-West differences in teen birth rates may be related to the weaker labor markets in East Germany.

Tables 5 and A.3 also present estimates with controls for lagged GDP growth at the state level. The results differ for the two data sources, but are imprecise in both cases. We find

21 As youth unemployment is traditionally rather low in Germany the lack of precision may be due to the small heterogeneity in youth unemployment over the business cycle. 
no clear correlation of teen fertility with GDP growth; this result holds up even when we do not control for unemployment (results not presented to save space). ${ }^{22}$

Finally, we test the marginalization hypothesis, i.e., that poverty is associated more strongly with teen pregnancy rates in situations of high regional income inequality (Kearney and Levine 2012a). Table 6 shows the correlation between income inequality at the state level and teen birth outcomes. The coefficients are insignificant for both datasets and independent of whether we use the $90 / 10$ or $50 / 10$ percentile ratios (see columns $1,3,5,7$ ). When we add interaction terms of income inequality and teenagers' economic background (see columns 2, 4, 6 , and 8 ) the coefficients of inequality and its interaction are statistically significant in the MZ sample (see columns 6 and 8). However, they show the opposite of the Kearney and Levine hypothesis: high regional inequality appears to attenuate the correlation between low household income and high teen fertility. Thus, we find no support for the Kearney and Levine (2012a) marginalization hypothesis. These results are robust to controls for state fixed effects. One might speculate that this result is connected to the comparatively generous German welfare system, which limits the extent of marginalization and hopelessness.

Finally, we study the explanatory power of different groups of variables for teen pregnancies. Controlling for year fixed effects we subsequently add different groups of variables (i.e., teen age, teen education, parent education, household characteristics, immigrant information, and aggregate measures) and test their joint significance. All variable groups are highly statistically significant with only small differences for immigrants.

So far, we presented all our results conditional only on year fixed effects. We performed two robustness tests. First, we additionally consider controls for 16 German federal states. This yields similar results for our first step estimations but substantial heterogeneities in aggregate characteristics across federal states: once we condition on state fixed effects, the

$22 \quad$ Additionally, we tested for correlation between teen birth and contemporaneous and twice lagged state GDP growth rates and found no significant correlation patterns. 
unemployment coefficients lose statistical significance in the MZ regressions; however, sign and magnitude of the estimates and the results for the other aggregate indicators remain unchanged.

In a second robustness test we consider individual level fixed effects using the longitudinal nature of our SOEP sample. This implies a change in specification as time invariant indicators (e.g., parental education or migration background) are omitted and a change in sample as only individuals with at least two observations can be used. The estimation results are robust (available upon request): the coefficients for the 'West Germany' indicators in Tables 4 and 5 become large and significant, which is likely connected to their identification based on regional movers in the new estimation setting. In Table 6 the results in columns 2 and 4 change with individual fixed effects: the main effect of household income turns positive and the interaction terms with income inequality yield negative coefficients. Again, this pattern of coefficients does not agree with the marginalization hypothesis thus confirming our earlier results.

\subsection{Time trends in teen fertility}

So far our analyses focused on the determinants of individual fertility outcomes in Germany as a low teen-fertility country. We can use our empirical framework to additionally shed light on the related issue of aggregate teen fertility trends. Figure 1.1 shows a decline in teen fertility in West Germany while the trend was positive in East Germany. We now use our large Mikrozensus samples for East and West Germany to study these developments. The estimation results in column 1 of Table 7 (7.1 for West and 7.2 for East Germany) describe teen fertility trends over time: the estimates confirm the different overall developments with an (insignificant) negative coefficient for West and a significant positive time trend for East Germany, where the trend variable is coded as year/100. In subsequent specifications we add the control variables that we considered before to determine their correlation with the time 
trend. The negative time trend in West Germany appears to be associated with the share of immigrants and with macroeconomic indicators such as unemployment, GDP growth, and income inequality. The time trend turns positive once these covariates are controlled for. In contrast, these variables do not account for the positive time trend for the East German sample: here, the trend coefficient remains significantly positive independent of the specification. Only when we use the full model does the trend coefficient decline in magnitude and lose precision. Overall this analysis confirms that aggregate macroeconomic indicators are associated with the trends in West Germany while the developments in East Germany after unification follow different patterns. ${ }^{23}$

\section{Conclusions}

This is one of the first empirical studies of teenage births in Germany. In Germany, the share of births to teen mothers in all births is small and declined from 4.9 to below 3.5 percent of all births between 1990 and 2010 (MPIDR 2012); overall, teen birth rates are 6.4 in 1,000 women in 2011. However these averages hide substantial regional heterogeneity. While teen births declined in West Germany, East German teen fertility rates are on the rise since 2004 and are now more than twice as high as those in West Germany. This phenomenon has not received public attention, so far. Unfortunately, the available micro-data for analyses of German teen fertility are limited. We use the German Socio-economic Panel (SOEP) and several years of the German Mikrozensus to study the patterns behind teen births.

The international literature on determinants and correlation patterns of teen fertility is dominated by contributions on non-marital teen births in the United States. The literature has identified different groups of determinants of teenage births: (a) individual and parental

\footnotetext{
23 The difference between the East and West German developments is a well known feature of post-unification demographic history; after unification fertility, marriage, and divorce rates underwent large negative shocks. They may not be driven by economic factors only and apparently take time to recover (for discussions see, e.g., Goldstein and Kreyenfeld 2011 or Chevalier and Marie 2013).
} 
background factors such as low education or low household income; (b) indicators of cyclical labor market developments; (c) state policies such as the availability of contraception and the generosity of welfare benefits; and (d) factors which indicate marginalization, i.e., poverty, unemployment, and the equality of the income distribution, which describe teen social background and perceived opportunities for a better life. The literature finds that the fertility of low educated teens responds to household income and marginalization. Also, there is evidence of substantial regional and ethnic heterogeneity in teen fertility in the United States.

In this study, we first show the incidence of teen fertility and its development over time in Germany. We describe the institutional framework including abortion regulations and welfare incentives. As we cannot observe pregnancies per se, our analyses are entirely based on teen births. We then test and show that the driving factors observed in the international literature can be confirmed for teenage fertility in Germany: individual age and education are correlated with fertility outcomes, as is parental background. We find that teen pregnancies increase in times of high (youth) unemployment, suggesting that opportunity costs may matter. Teen fertility is higher in East than in West Germany and among immigrants than among natives. The east-west difference loses statistical significance as soon as we account for household or aggregate unemployment, which suggests that the labor market plays a central role in explaining regional teen fertility differences. Possibly, teen births decline if youths from disadvantaged backgrounds and with low educational attainment enter the labor market more easily and see lifetime opportunities for themselves.

A question of potential policy relevance concerns the increasing difference in teen fertility between East and West Germany and the recent rise in East German teen fertility. Chevalier and Marie (2013) offer an explanation as they show that the children born in East Germany immediately upon reunification, i.e., at a time when fertility had dropped by about fifty percent, suffer from a negative selection of their parents. The authors show that crime rates are higher among these "children of the wall", i.e., individuals born in East Germany 
between 1991 and 1993. Our evidence from aggregate birth rates suggests that the "children of the wall" may also be subject to a higher incidence of teen pregnancy. Unfortunately, our samples do not yet allow us to reliably test the "children of the wall" hypothesis, as they hardly cover the relevant birth cohorts. However, this promises to be an intriguing research question for future analyses. 


\section{Bibliography}

Aassve, Arnstein, 2003, The impact of economic resources on premarital childbearing and subsequent marriage among young American women, Demography 40(1), 105-126.

Arkes, Jeremy, and Jacob Alex Klerman, 2009, Understanding the link between the economy and teenage sexual behavior and fertility outcomes, Journal of Population Economics 22 (3), 517-536.

Baird, Sarah, Ephraim Chriwa, Craig McIntosh, and Berk Özler, 2010, The Short-Term Impacts of a Schooling Conditional Cash Transfer Program on the Sexual Behavior of Young Women, Health Economics 19, 55-68.

Black, Sandra E., Paul J. Devereux, and Kjell G. Salvanes, 2008, Staying in the classroom and out of the maternity ward? The effect of compulsory schooling laws on teenage births, Economic Journal 118(530), 1025-1054.

Blank, Rebecca M., 1995, Teen Pregnancy: Government Progams Are Not the Cause, Feminist Economics 1(2), 47-58.

Blomeyer, Dorothea, Manfred Laucht, Katja Coneus, and Friedhelm Pfeiffer, 2013, Early Life Adversity and Children's Competence Development: Evidence from the Mannheim Study of Children at Risk, Journal of Economics and Statistics (Jahrbücher für Nationalökonomie und Statistik) 233(4), 467-485.

BZgA (Bundeszentrale für gesundheitliche Aufklärung), 2006, Jugendsexualität. Repräsentative Wiederholungsbefragung von 14- bis 17-Jährigen und ihren Eltern, Köln.

BZgA (Bundeszentrale für gesundheitliche Aufklärung), 2010, Jugendsexualität. Repräsentative Wiederholungsbefragung von 14- bis 17-Jährigen und ihren Eltern - Aktueller Schwerpunkt Migration, Köln.

Cardoso, Ana Rute and Dorte Verner, 2008, Youth Risk-Taking Behavior in Brazil: Drug Use and Teenage Pregnancy, World Bank Policy Research Working Paper 4548, World Bank.

Chevalier, Arnaud and Olivier Marie, 2013, Economic uncertainty, parental selection and the criminal activity of the 'Children of the Wall', CESifo Working Paper No. 4462, Munich.

Darroch, Jacqueline E., Susheela Singh, Jennifer J. Frost, and the Study Team, 2001, Differences in Teenage Pregnancy Rates Among Five Developed Countries: The Roles of Sexual Activity and Contraceptive Use, Family Planning Perspectives 33(6), 244-250.

Emmerling, Dieter, 2012, Geburten, Sterbefälle, Eheschließungen, Wirtschaft und Statistik Sommer 2012, 744-759.

Franz, Jutta and Ulrike Busch, 2004, Schwangerschaften Minderjähriger - Hintergründe und beraterische Anforderungen, BZgA Forum 2004(4), 10-16.

Friedrich, Monika and Annette Remberg, 2005, Wenn Teenager Eltern werden ... Lebenssituation Jugendlicher Schwangerer und Mütter sowie Jugendlicher Paare mit Kind, Band 25: Forschung und Praxis der Sexualaufklärung und Familienplanung, Bundeszentrale für gesundheitliche Aufklärung, Köln.

Goldstein, Joshua R. and Michaela Kreyenfeld, 2011, Has East Germany overtaken West Germany? Recent trends in order-specific fertility, Population and Development Review 37(3), 453-472.

Hao, Lingxin, Nan M. Astone, and Andrew J. Cherlin, 2007, Effects of child support and welfare policies on nonmarital teenage childbearing and motherhood, Population Research and Policy Review 26(3), 235-247.

Jones, Elise F. and Jacqueline Darroch Forrest, 1987, Teenage Pregnancy in Industrialized Countries, Yale University Press, New Haven and London.

Kearney, Melissa S. and Phillip B. Levine, 2012a, Why is the Teen Birth Rate in the United States So High and Why Does It Matter? Journal of Economic Perspectives 26(2), 141-166.

Kearney, Melissa S. and Phillip B. Levine, 2012b, Explaining Recent Trends in the U.S. Teen Birth Rate, NBER Working Paper 17964, Cambridge, Mass.

Keller, Sabine, 2011, Biographical Consequences of Teenage Motherhood in Germany, Schmollers Jahrbuch 131(2), 235-252. 
Kruger, Diana I., Matias Berthelon, and Rodrigo Navia, 2009, Adolescent Motherhood and Secondary Schooling in Chile, IZA Discussion Paper No. 4552, IZA Bonn.

Levine, Phillip B., 2001, The Sexual Activity and Birth-Control Use of American Teenagers, in: Gruber, Jonathan (ed.) Risky Behavior Among Youths: An Economic Analysis, University of Chicago Press, Chicago, 167-217.

Levine, Phillip B., 2002, The Impact of Social Policy and Economic Activity Throughout the Fertility Decision Tree, NBER Working Paper No. 9021, Cambridge, Mass.

Lundberg, Shelly and Robert D. Plotnick, 1995, Adolescent Premarital Childbearing: Do Economic Incentives Matter?, Journal of Labor Economics 13(2), 177-200.

Lupton, Ruth and Dylan Kneale, 2010, Are there neighbourhood effects on teenage parenthood in the UK and does it matter for policy? A review of theory and evidence, CASE/141, Centre for Analysis of Social Exclusion Discussion Paper, London.

Miranne, Kristine B. and Alma H. Young, 2002, Teen Mothers and Welfare Reform: Challenging the Boundaries of Risk, Journal of Family and Economic Issues 23(4), 361-379.

Monstad, Karin, Carol Propper, and Kjell G. Salvanes, 2011, Is Teenage Motherhood Contagious? Evidence from a Natural Experiment, CMPO Working Paper Series No. 11/262, University of Bristol.

MPIDR (Max Planck Institute for Demographic Research), 2012, Human Fertility Database, available at www.humanfertility.org (data downloaded on [20.09.2012])

Riphahn, Regina T., 2003, Cohort Effects in the Educational Attainment of Second Generation Immigrants in Germany: An Analysis of Census Data, Journal of Population Economics 16(4), 711-737.

Riphahn, Regina T., Monika Sander, and Christoph Wunder, 2013, The Welfare Use of Immigrants and Natives in Germany: The Case of Turkish Immigrants, International Journal of Manpower 34(1), 70-82.

Singh, Susheela and Jacqueline E. Darroch, 2000, Adolescent Pregnancy and Childbearing: Levels and Trends in Developed Countries, Family Planning Perspectives 32(1), 14-23.

STBA (Statistisches Bundesamt), 1995, Fachserie 1 Bevölkerung und Erwerbstätigkeit, Reihe 3 Haushalt und Familie, Wiesbaden.

STBA (Statistisches Bundesamt), 2006, Leben in Deutschland - Haushalte Familien und Gesundheit, Ergebnisse des Mikrozensus 2005, Pressebrochüre, Wiesbaden.

STBA (Statistisches Bundesamt), 2010, Statistik der natürlichen Bevölkerungsbewegung, Wiesbaden.

Ventura, Stephanie J., Sally C. Curtin, Joyce C. Abma, and Stanley K. Henshaw, 2012, Estimated pregnancy rates and rates of pregnancy outcomes for the United States, 1990-2008, National Vital Statistics Reports 60(7), 1-21. Available at: http://www.cdc.gov/nchs/data/nvsr/nvsr60/nvsr60_07.pdf(download 21.09.2012).

Wagner, Gert G., Joachim R. Frick, and Jürgen Schupp, 2007, The German Socio-Economic Panel Study (SOEP) - scope, evolution and enhancemants, Schmollers Jahrbuch (Journal of Applied Social Science Studies) 127(1), 139-169.

Wolfe, Barbara, Kathryn Wilson, and Robert Haveman, 2001, The role of economic incentives in teenage nonmarital childbearing decisions, Journal of Public Economics 81(3), 473-511.

Wolfe, Barbara, Robert Haveman, Karen Pence, Jonathan A. Schwabish, 2007, Do youth nonmarital childbearing choices reflect income and relationship expectations? Journal of Population Economics 20(1), 73-100. 
Figure 1 Fertility rates in East and West Germany over time

1.1 Teen fertility: annual births for 1,000 women (age 15-19)

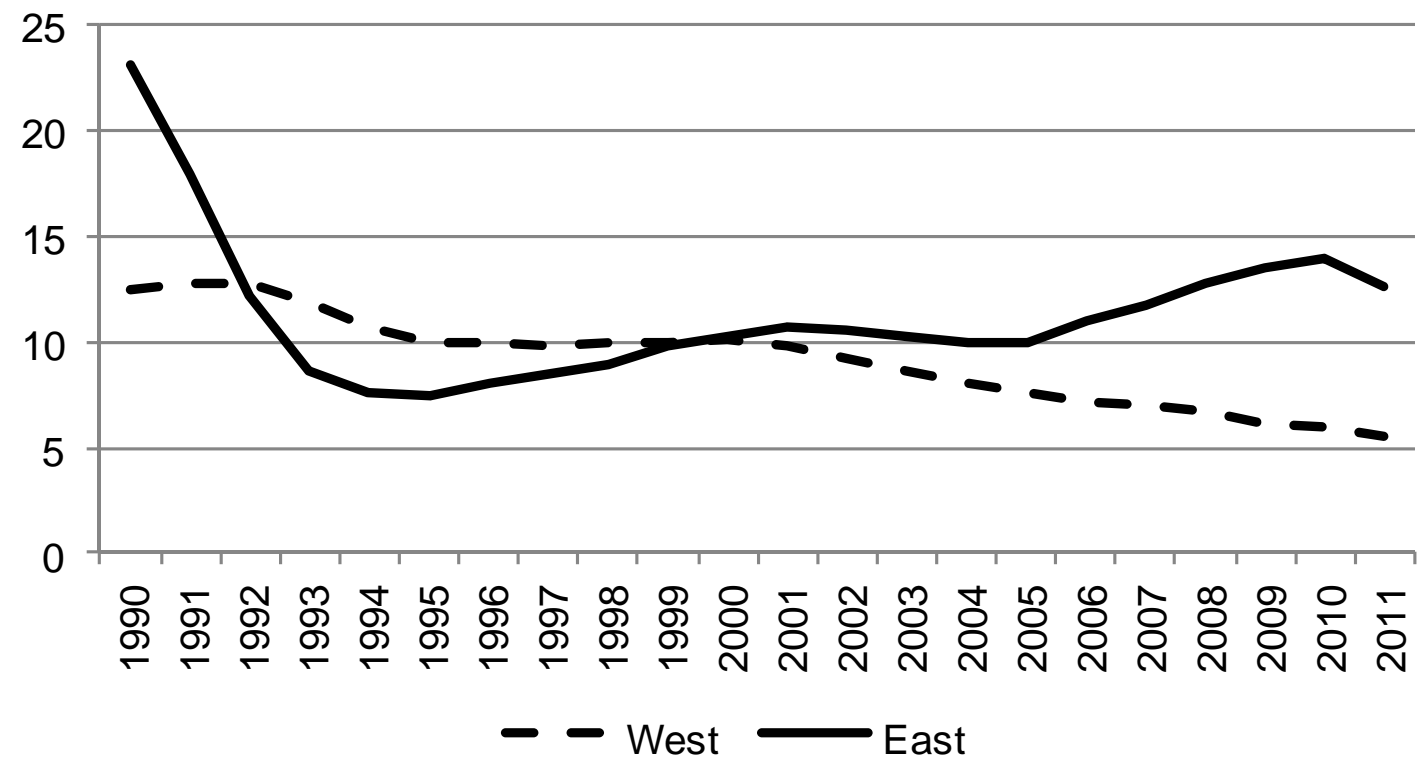

1.2 Total fertility rate (age 15-49)

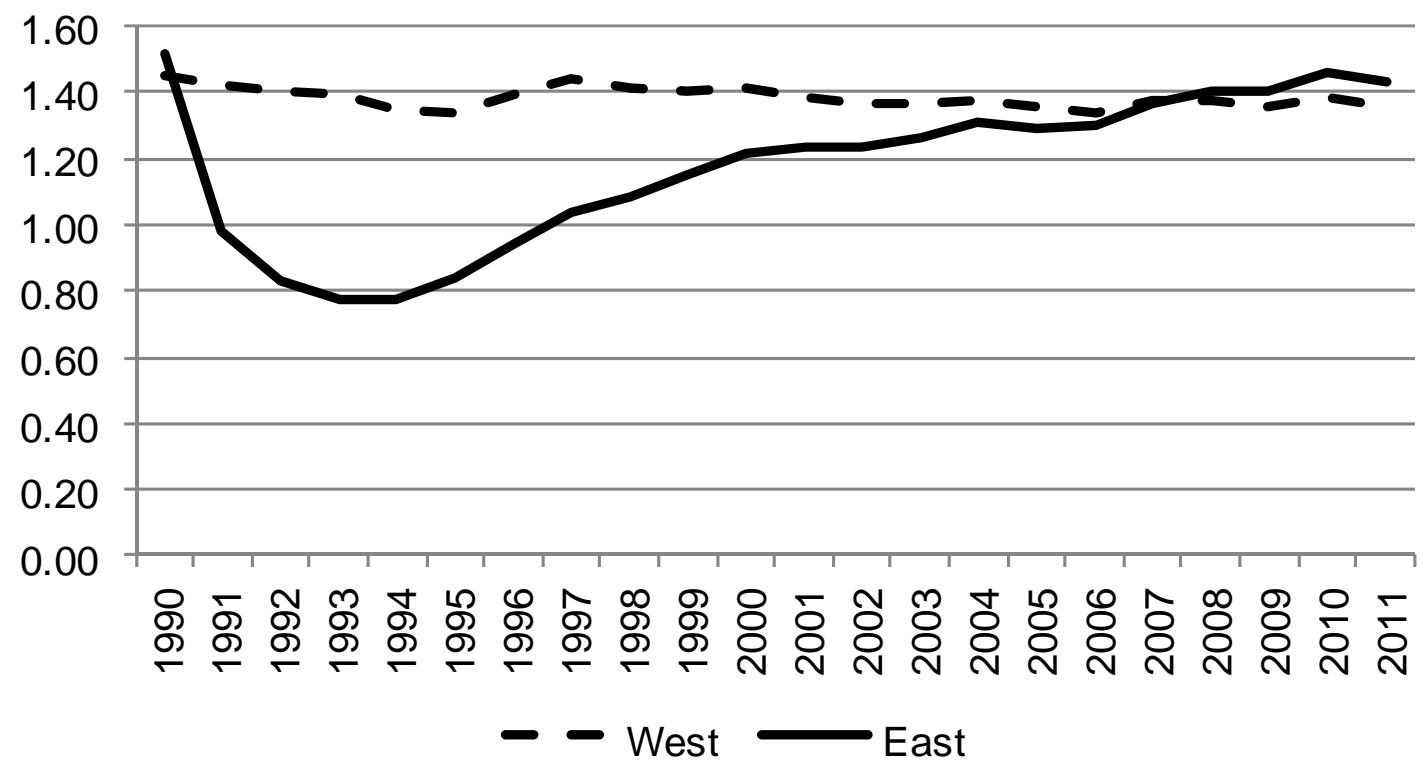

Source: The data on teen births were provided upon request via electronic mail by German Federal Statistical Office. 
Figure 2 Share of abortions in pregnancies for females below age 20

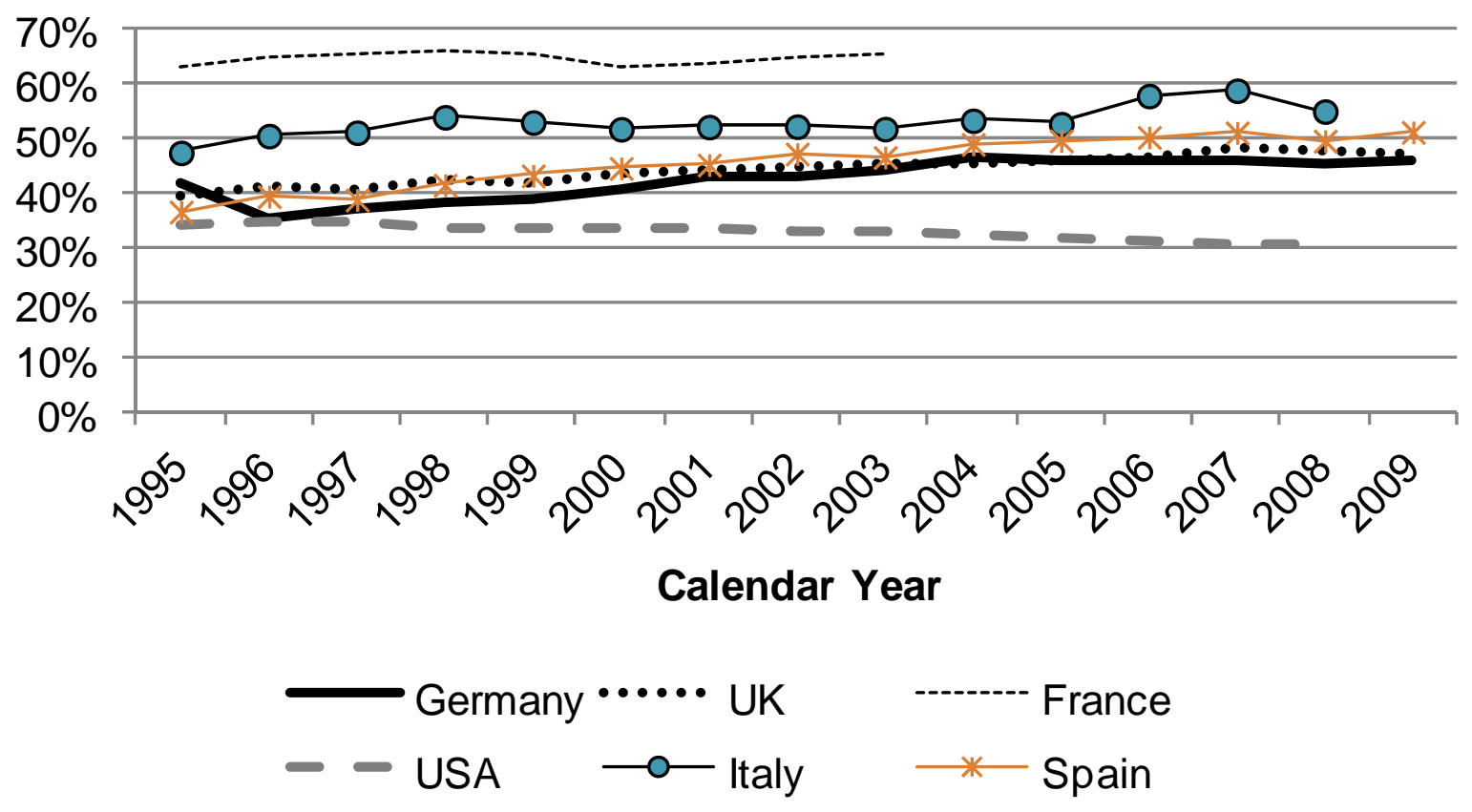

Source: All but the U.S. data are taken from the WHO database European health for all, http://data.euro.who.int/hfadb/ (last access Sept. 21, 2012). The U.S. data are from Ventura et al. (2012). 
Figure 3 Abortion rates in East and West Germany over time

3.1 Teen abortion rate - ages 15-19 (number of abortions / 1000 women)

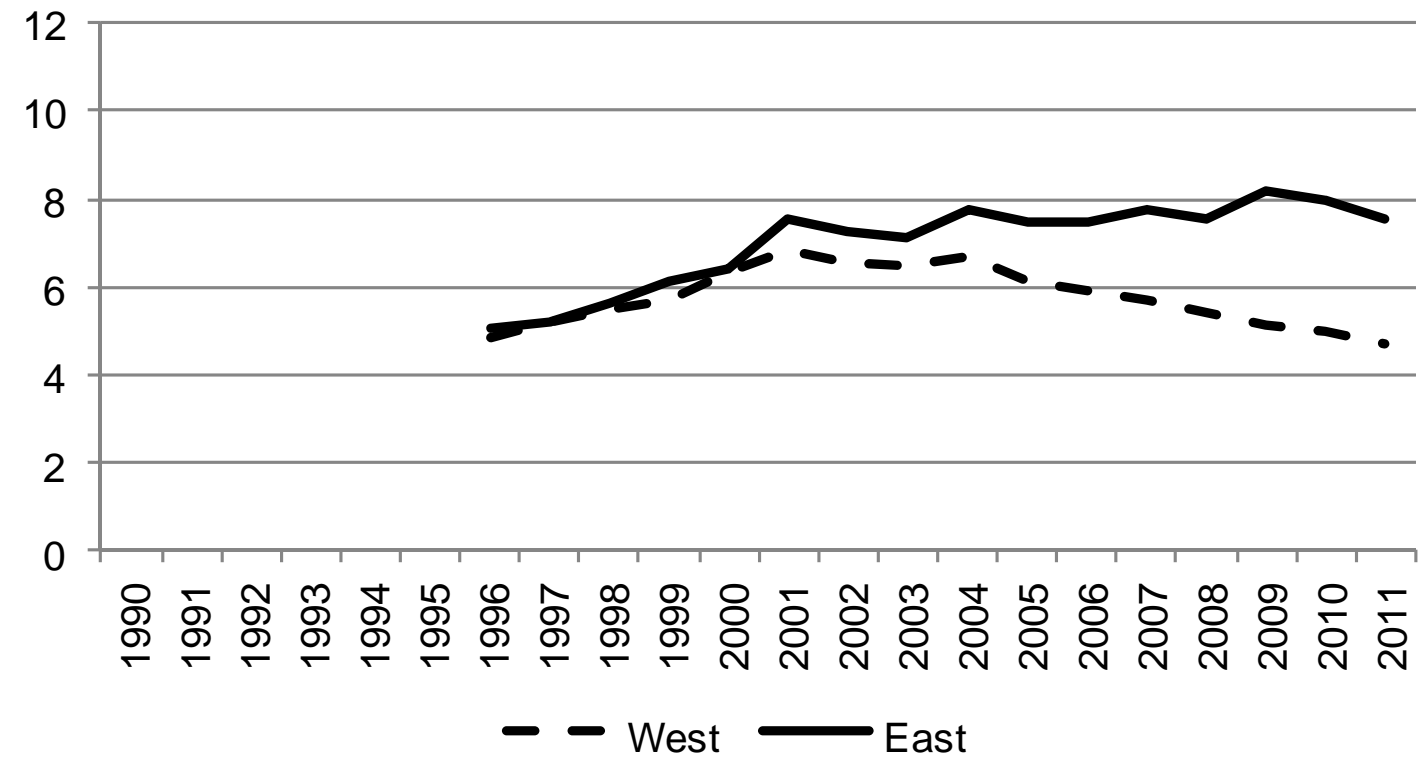

3.2 Abortion rate - ages 15-44 (number of abortions / 1000 women)
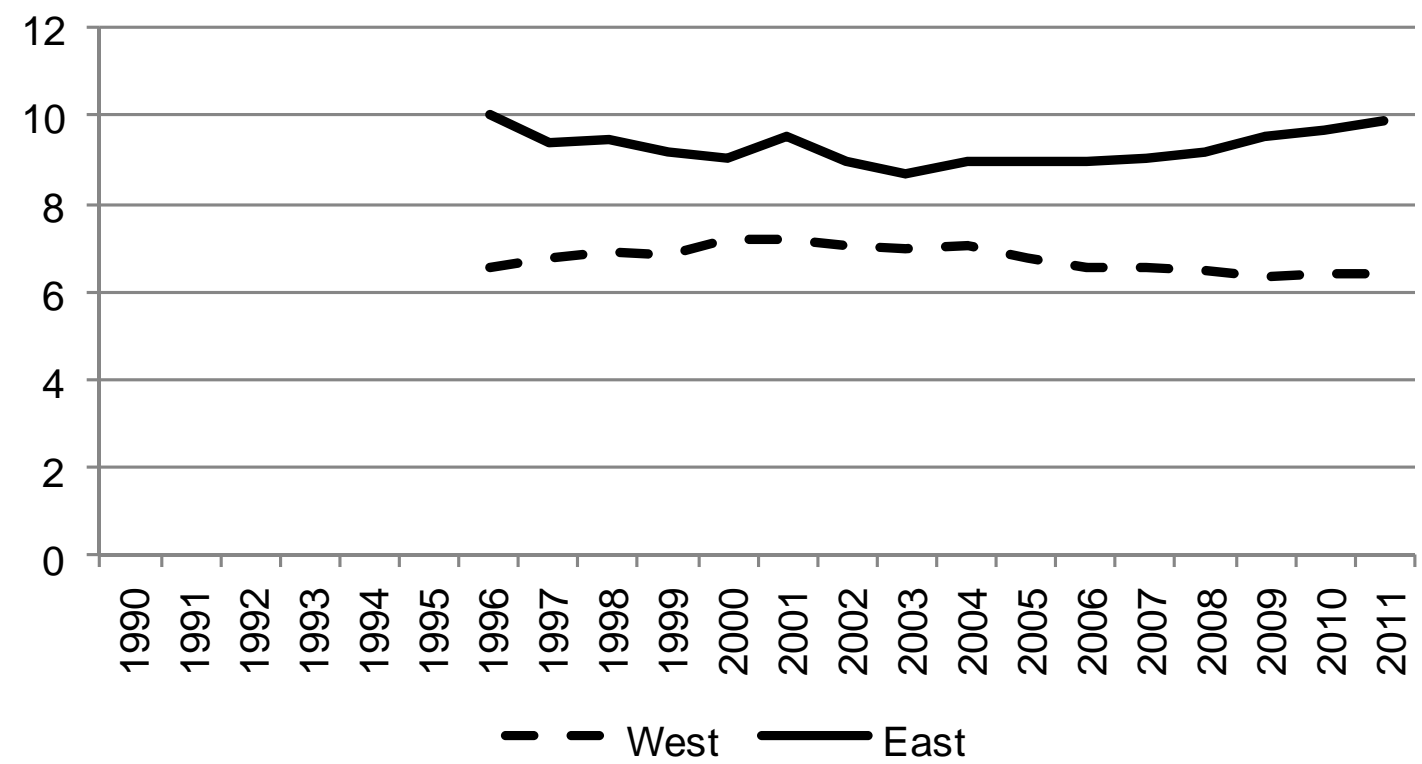
3.3 Share of abortions in all teenage pregnancies (age 15-19)

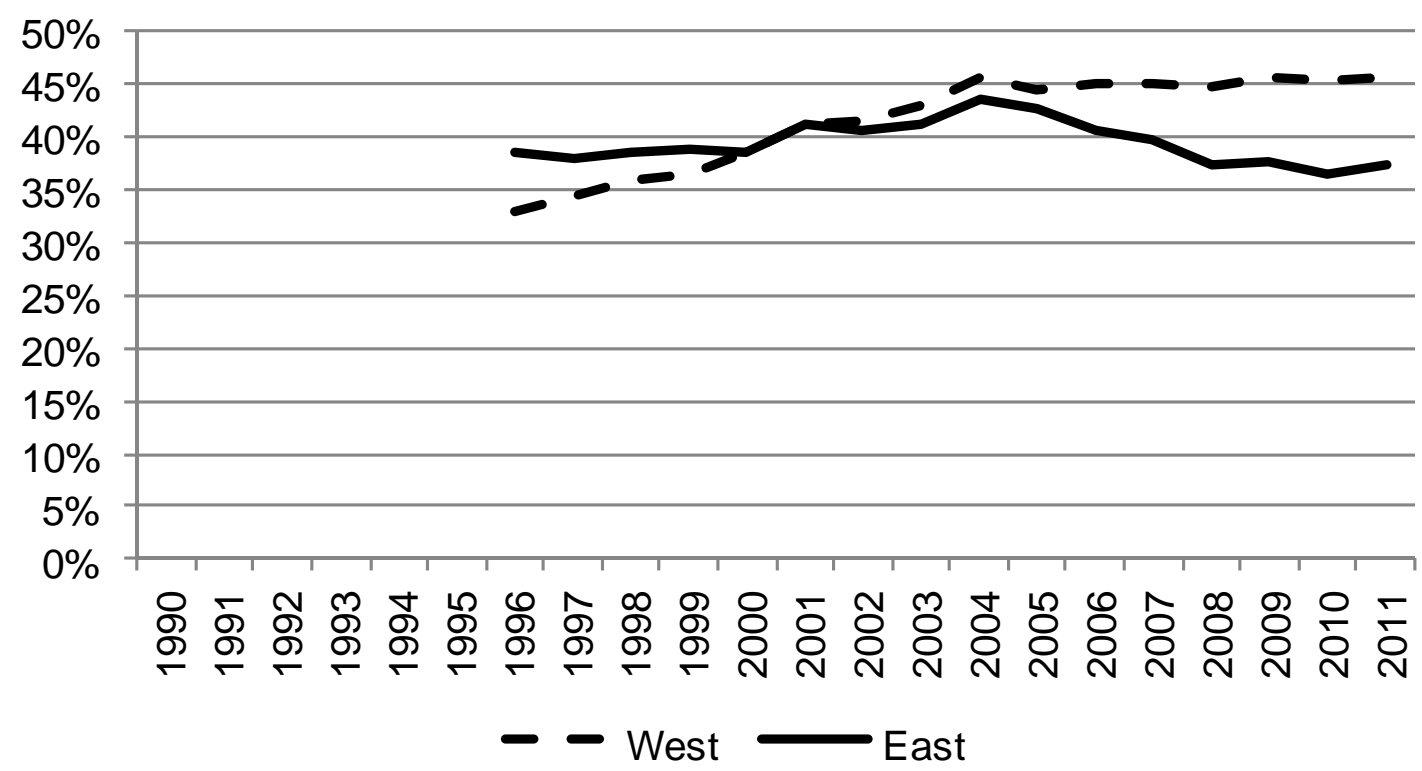

Note: Figures 3.1 and 3.2 present the number abortions per 1,000 women in any given calendar year. Figure 3.3 combines the information on abortion and birth rates. Please note that the birth and abortion statistics differ in the definition of maternal age: age at birth is the difference between the birth years of mother and child, and age at abortion reflects a woman's completed age. Combining these figures only approximates the developments for age groups and for calendar years but cannot be exact because of diverging definitions. The teen abortion rates in Figure 3.2 are calculated based on state-level data for age-groups provided by German Federal Statistical Office for the years 1996-2010. Birth rates omit the state of Berlin from 2001 onwards, and abortion rates omit it throughout.

Source: The data were provided upon request via electronic mail by German Federal Statistical Office. Figures are based on own calculations. 
Figure 4 Share of teen females with a first birth (in 1,000)

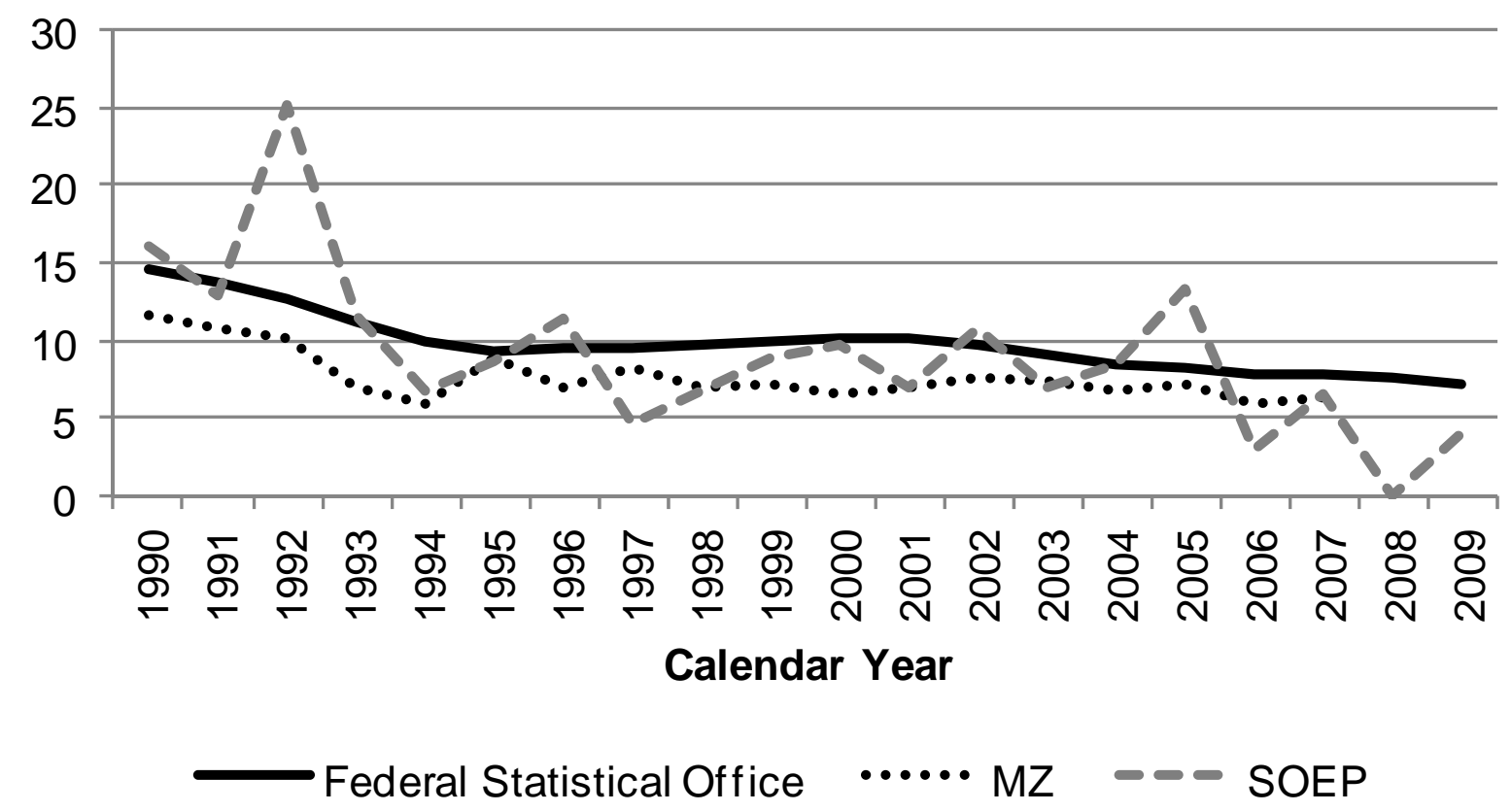

Note: The data from the Federal Statistical Office considers teens aged 15-19, while the MZ and SOEP data are based on the age groups 16-19. Also, the survey data only consider first births. The Mikrozensus data are gathered in the five survey years as described in the text (1991, 1995, 1999, 2003, 2007). In every survey year the share of teen births was coded for the four years preceding each survey; as the survey is gathered in the first half of the calendar year we do not observe the complete number of teen births for the survey year and therefore the survey year itself is not used; instead we use information on the years t- 1 through $\mathrm{t}-4$ for every survey year.

Source: STBA (2010), and own calculations based on Mikrozensus and SOEP data. 
Table 1 Teenage fertility rates across countries (1998-2009)

\begin{tabular}{lrrrr}
\hline Country & $\mathbf{1 9 9 8}$ & $\mathbf{2 0 0 0}$ & $\mathbf{2 0 0 5}$ & $\mathbf{2 0 0 9}$ \\
\hline Euro area & 10.2 & 10.1 & 9.1 & 7.8 \\
European Union & 16.7 & 15.9 & 14.2 & 12.2 \\
OECD members & 33.3 & 31.9 & 28.6 & 25.7 \\
World & 63.0 & 60.2 & 53.5 & 50.3 \\
\hline Australia & 19.0 & 18.0 & 15.8 & 13.8 \\
Austria & 14.5 & 14.0 & 13.1 & 11.8 \\
Belgium & 9.4 & 9.0 & 8.1 & 7.3 \\
Czech Republic & 16.3 & 14.6 & 11.6 & 10.4 \\
Denmark & 7.9 & 7.3 & 6.3 & 5.7 \\
Finland & 10.0 & 11.4 & 12.3 & 10.6 \\
France & 7.3 & 7.6 & 7.5 & 6.4 \\
Germany & 12.5 & 11.6 & $\mathbf{9 . 1}$ & 7.2 \\
Greece & 11.6 & 10.8 & 9.4 & 8.3 \\
Hungary & 28.6 & 26.3 & 21.8 & 18.8 \\
Italy & 7.0 & 7.0 & 6.0 & 4.6 \\
Japan & 4.5 & 5.1 & 5.3 & 4.8 \\
Netherlands & 4.6 & 4.9 & 4.5 & 3.7 \\
Norway & 12.2 & 11.1 & 9.1 & 8.0 \\
Poland & 19.1 & 17.4 & 14.6 & 13.4 \\
Portugal & 20.1 & 19.9 & 18.1 & 15.2 \\
Romania & 41.2 & 38.6 & 33.3 & 29.3 \\
Russian Federation & 34.9 & 31.8 & 26.5 & 24.0 \\
Spain & 8.2 & 9.2 & 11.2 & 11.5 \\
Sweden & 8.8 & 8.5 & 7.9 & 7.2 \\
Switzerland & 5.8 & 5.7 & 5.5 & 5.2 \\
Turkey & 51.1 & 47.4 & 40.8 & 35.9 \\
United Kingdom & 29.5 & 28.5 & 25.7 & 22.2 \\
United States & 51.3 & 47.6 & 39.5 & 32.6 \\
\hline & & & & \\
& & & & \\
& & & &
\end{tabular}

Note: Presented is the fertility rate, i.e. the number of births per 1,000 women, for those aged 15-19 in a given year.

Source: United Nations Population Division, World Population Prospects. 
Table 2 Results - Step 1: Micro-level patterns

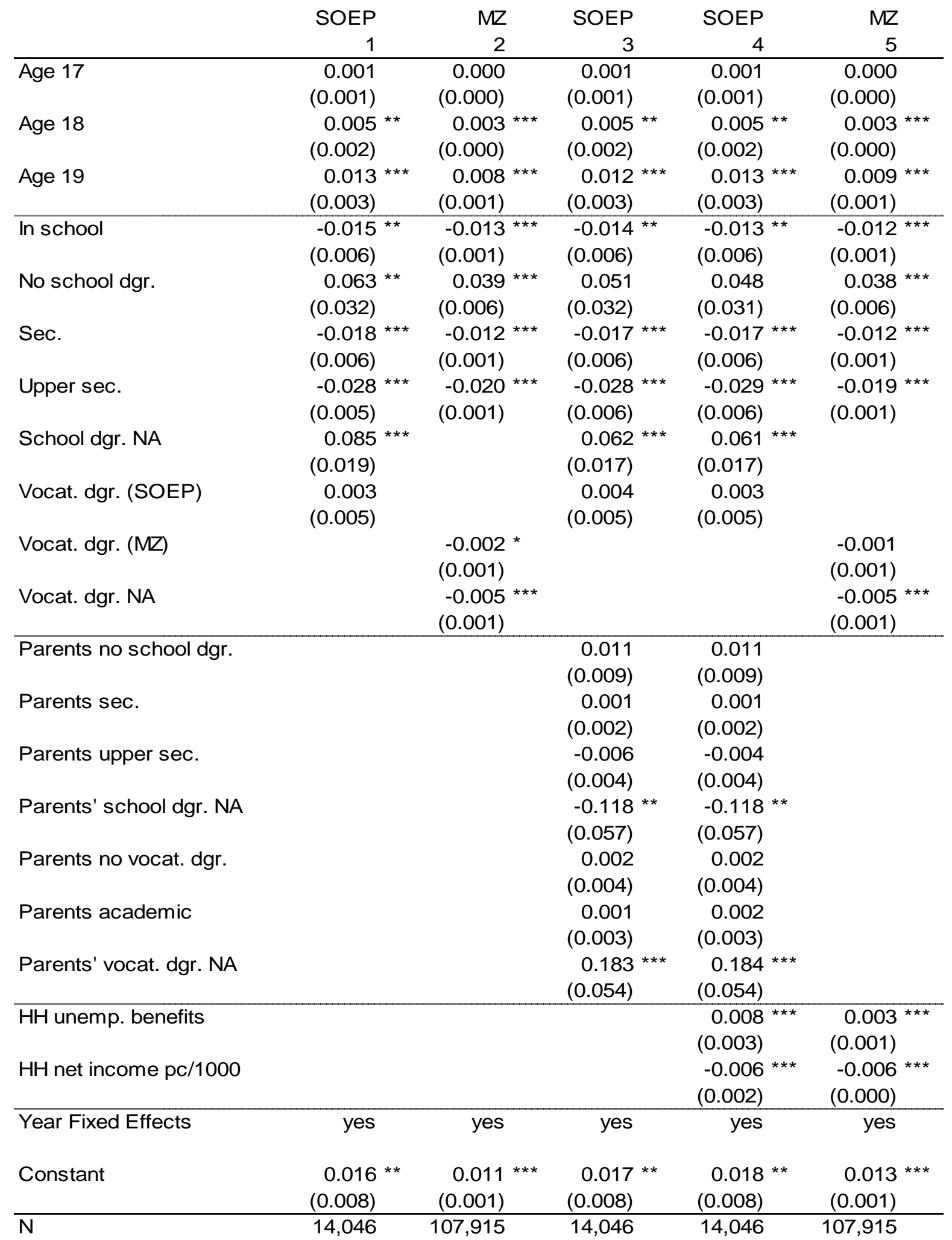

Note: $* * *$, and $* * *$ indicate statistical significance at the 10,5 , and 1 percent level. 
Table 3 Results - Step 1: Micro-level patterns plus migration

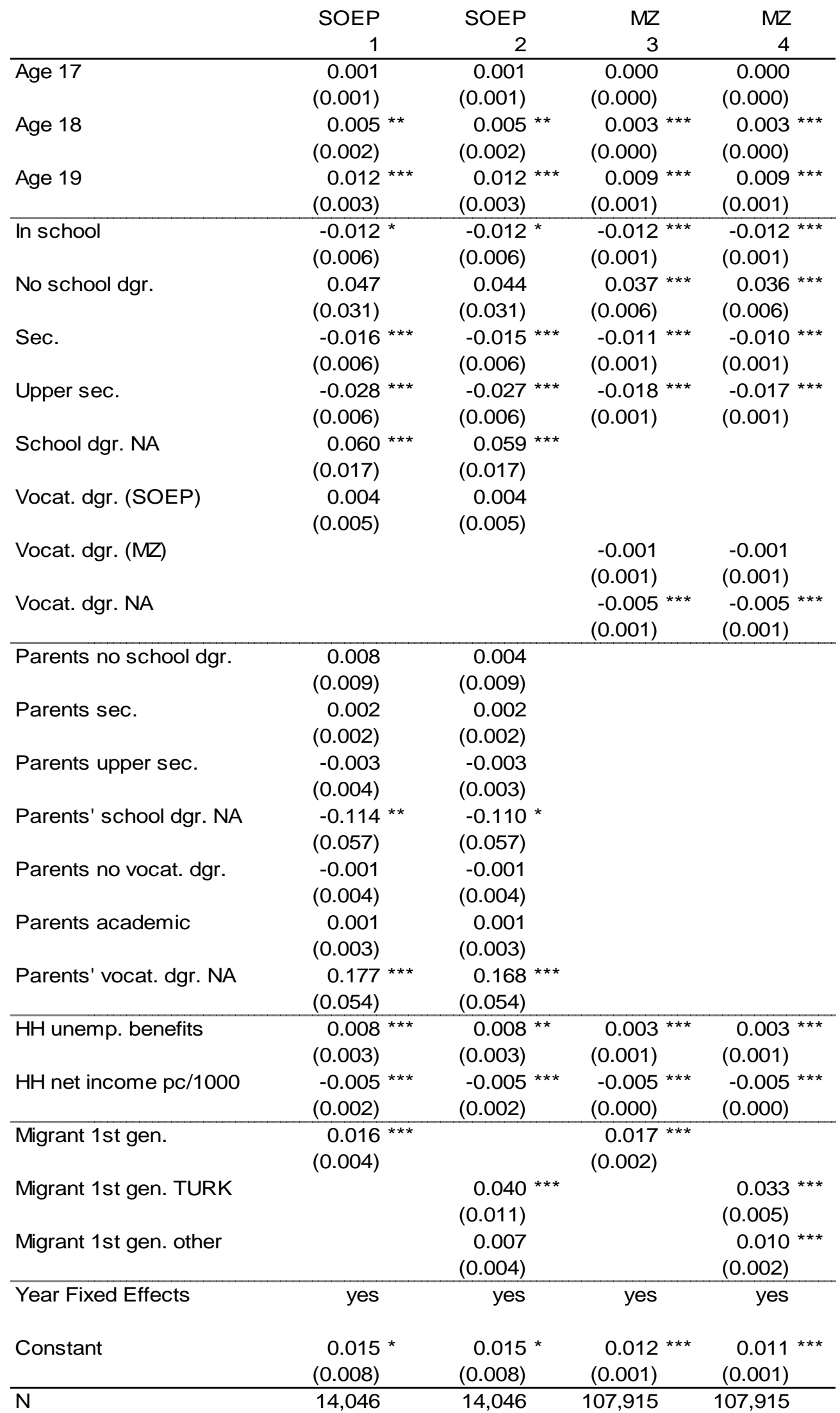

Note: $* * *$, and $* * *$ indicate statistical significance at the 10,5 , and 1 percent level. 
Table 4 Conditional East-West Difference in Teen Fertility

\begin{tabular}{|c|c|c|c|c|c|c|c|c|c|}
\hline & SOEP & SOEP & SOEP & SOEP & SOEP & MZ & MZ & MZ & MZ \\
\hline & 1 & 2 & 3 & 4 & 5 & 6 & 7 & 8 & 9 \\
\hline \multirow[t]{2}{*}{ West Germany } & -0.002 & -0.002 & -0.003 & -0.005 ** & -0.002 & 0.000 & 0.000 & -0.001 ** & -0.001 \\
\hline & $(0.002)$ & $(0.002)$ & $(0.002)$ & $(0.002)$ & $(0.002)$ & (0.001) & $(0.001)$ & $(0.001)$ & $(0.001)$ \\
\hline Teen Age & - & yes & yes & yes & yes & - & yes & yes & yes \\
\hline Teen Education & - & - & yes & yes & yes & - & - & yes & yes \\
\hline Parental Education & - & - & - & yes & yes & - & - & - & \\
\hline HH unemp.\& inc. & - & - & - & - & yes & - & - & - & yes \\
\hline Year FE, constant & yes & yes & yes & yes & yes & yes & yes & yes & yes \\
\hline $\mathrm{N}$ & 10,359 & 10,359 & 10,359 & 10,359 & 10,359 & 86,312 & 86,312 & 86,312 & 86,312 \\
\hline
\end{tabular}

Note: $* * *$, and $* * *$ indicate statistical significance at the 10,5 , and 1 percent level. 
Table 5 Results - Step 2: Aggregate determinants

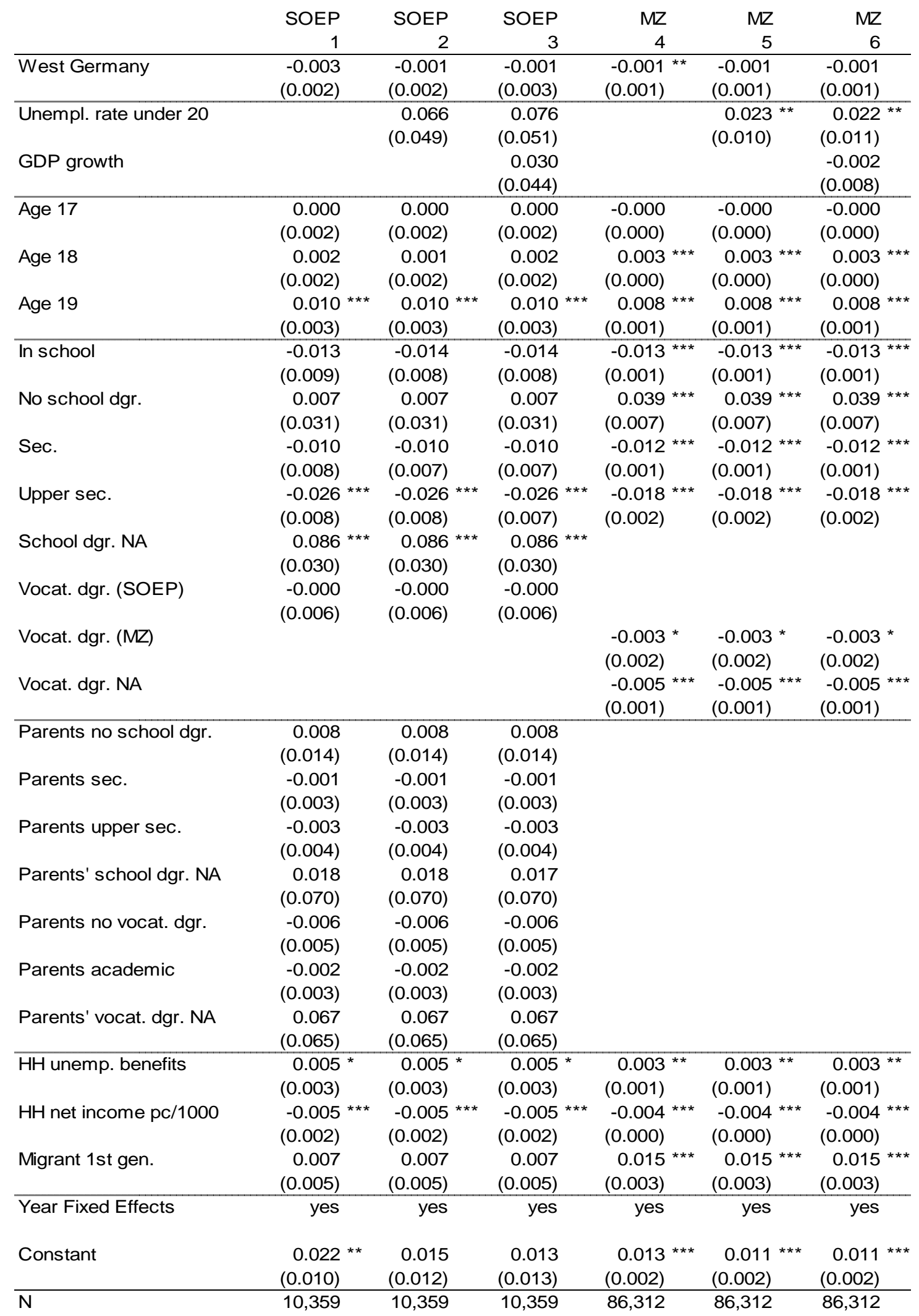

Note: $* * *$, and $* * *$ indicate statistical significance at the 10,5 , and 1 percent level. 
Table 6 Inequality and inequality interaction terms

\begin{tabular}{|c|c|c|c|c|c|c|c|c|}
\hline & SOEP & SOEP & SOEP & SOEP & $M Z$ & $\mathrm{MZ}$ & $\mathrm{MZ}$ & $M Z$ \\
\hline & 1 & 2 & 3 & 4 & 5 & 6 & 7 & 8 \\
\hline \multirow[t]{2}{*}{ West Germany } & -0.003 & -0.002 & -0.001 & -0.001 & 0.000 & 0.001 & -0.000 & -0.000 \\
\hline & $(0.006)$ & $(0.006)$ & $(0.003)$ & $(0.003)$ & $(0.001)$ & $(0.001)$ & $(0.001)$ & $(0.001)$ \\
\hline \multirow[t]{2}{*}{ Unempl. rate under 20} & 0.062 & 0.062 & 0.066 & 0.066 & $0.030 * \star$ & $0.030 * *$ & $0.027 * \star$ & $0.027 * \star$ \\
\hline & $(0.060)$ & $(0.060)$ & $(0.055)$ & $(0.055)$ & $(0.012)$ & $(0.012)$ & $(0.012)$ & $(0.012)$ \\
\hline \multirow[t]{2}{*}{ GDP growth } & 0.032 & 0.029 & 0.034 & 0.034 & -0.002 & -0.002 & -0.003 & -0.003 \\
\hline & $(0.043)$ & $(0.043)$ & $(0.043)$ & $(0.042)$ & $(0.008)$ & $(0.008)$ & $(0.008)$ & $(0.008)$ \\
\hline \multirow[t]{2}{*}{ Inequality ratio 90/10 } & 0.002 & 0.001 & & & -0.001 & $-0.004 * \star \star$ & & \\
\hline & $(0.005)$ & $(0.006)$ & & & $(0.001)$ & $(0.001)$ & & \\
\hline \multirow[t]{2}{*}{ Ineq.9010 * $\mathrm{HH}$ net income } & & 0.002 & & & & $0.003 * * *$ & & \\
\hline & & $(0.003)$ & & & & $(0.001)$ & & \\
\hline \multirow[t]{2}{*}{ Inequality ratio 50/10 } & & & 0.004 & 0.005 & & & -0.002 & $-0.009 * \star$ \\
\hline & & & $(0.010)$ & $(0.015)$ & & & $(0.002)$ & $(0.004)$ \\
\hline \multirow[t]{2}{*}{ Ineq. 5010 * $\mathrm{HH}$ net income } & & & & -0.000 & & & & $0.009 * * *$ \\
\hline & & & & $(0.012)$ & & & & $(0.003)$ \\
\hline \multirow[t]{2}{*}{ Age 17} & 0.000 & 0.000 & 0.000 & 0.000 & -0.000 & -0.000 & -0.000 & -0.000 \\
\hline & $(0.002)$ & $(0.002)$ & $(0.002)$ & $(0.002)$ & $(0.000)$ & $(0.000)$ & $(0.000)$ & $(0.000)$ \\
\hline \multirow[t]{2}{*}{ Age 18} & 0.002 & 0.002 & 0.002 & 0.002 & $0.003 * * *$ & $0.003 * * *$ & $0.003 * * \star$ & $0.003 * * *$ \\
\hline & $(0.002)$ & $(0.002)$ & $(0.002)$ & $(0.002)$ & $(0.000)$ & $(0.000)$ & $(0.000)$ & $(0.000)$ \\
\hline \multirow[t]{2}{*}{ Age 19} & $0.010 * * \star$ & $0.010 * \star \star$ & $0.010 * \star \star$ & $0.010 * \star \star$ & $0.008 * * \star$ & $0.008 * \star \star$ & $0.008 * * \star$ & $0.008 * * *$ \\
\hline & (0.003) & (0.003) & (0.003) & (0.003) & (0.001) & (0.001) & (0.001) & (0.001) \\
\hline \multirow[t]{2}{*}{ In school } & -0.014 & -0.014 & -0.014 & -0.014 & $-0.013 * \star *$ & $-0.013 * \star \star$ & $-0.013 * * \star$ & $-0.013 * * \star$ \\
\hline & (0.008) & (0.008) & (0.008) & (0.008) & (0.001) & (0.001) & (0.001) & (0.001) \\
\hline \multirow[t]{2}{*}{ No school dgr. } & 0.007 & 0.007 & 0.007 & 0.007 & $0.039 * * \star$ & $0.039 * * \star$ & $0.039 * * \star$ & $0.039 * * *$ \\
\hline & (0.031) & (0.031) & (0.031) & (0.031) & (0.007) & (0.007) & (0.007) & $(0.007)$ \\
\hline \multirow[t]{2}{*}{ Sec. } & -0.010 & -0.010 & -0.010 & -0.010 & $-0.012 * \star *$ & $-0.012 * * *$ & $-0.012 * * \star$ & $-0.012 * * *$ \\
\hline & (0.007) & $(0.007)$ & $(0.007)$ & (0.007) & (0.001) & $(0.001)$ & (0.001) & (0.001) \\
\hline \multirow[t]{2}{*}{ Upper sec. } & $-0.026 * \star *$ & $-0.026 * * *$ & $-0.026 * \star *$ & $-0.026 * \star \star$ & $-0.018 * \star \star$ & $-0.018 * * *$ & $-0.018 * \star \star$ & $-0.018 * * *$ \\
\hline & $(0.007)$ & $(0.007)$ & $(0.007)$ & $(0.007)$ & $(0.002)$ & $(0.002)$ & $(0.002)$ & (0.002) \\
\hline School dgr. NA & $0.086 * \star \star$ & $0.086 * \star *$ & $0.086 * \star *$ & $0.086 * \star \star$ & & & & \\
\hline & $(0.030)$ & $(0.030)$ & $(0.030)$ & $(0.030)$ & & & & \\
\hline Vocat. dgr. (SOEP) & -0.000 & -0.000 & -0.000 & -0.000 & & & & \\
\hline & $(0.006)$ & $(0.006)$ & $(0.006)$ & $(0.006)$ & & & & \\
\hline Vocat. dgr. (MZ) & & & & & $-0.003 *$ & $-0.003 *$ & $-0.003 *$ & $-0.003 *$ \\
\hline & & & & & $(0.002)$ & $(0.002)$ & $(0.002)$ & $(0.002)$ \\
\hline Vocat. dgr. NA & & & & & $-0.005 * \star \star$ & $-0.005 * * *$ & $-0.005 * \star \star$ & $-0.005 * * *$ \\
\hline & & & & & $(0.001)$ & (0.001) & $(0.001)$ & (0.001) \\
\hline Parents no school dgr. & 0.008 & 0.008 & 0.008 & 0.008 & & & & \\
\hline & $(0.014)$ & $(0.014)$ & $(0.014)$ & $(0.014)$ & & & & \\
\hline Parents sec. & -0.001 & -0.001 & -0.001 & -0.001 & & & & \\
\hline & $(0.003)$ & $(0.003)$ & $(0.003)$ & $(0.003)$ & & & & \\
\hline Parents upper sec. & -0.003 & -0.003 & -0.003 & -0.003 & & & & \\
\hline & $(0.004)$ & $(0.004)$ & $(0.004)$ & $(0.004)$ & & & & \\
\hline Parents' school dgr. NA & 0.017 & 0.017 & 0.017 & 0.017 & & & & \\
\hline & $(0.070)$ & $(0.070)$ & $(0.070)$ & $(0.070)$ & & & & \\
\hline Parents no vocat. dgr. & -0.006 & -0.006 & -0.006 & -0.006 & & & & \\
\hline & $(0.005)$ & $(0.005)$ & $(0.005)$ & $(0.005)$ & & & & \\
\hline Parents academic & -0.002 & -0.002 & -0.002 & -0.002 & & & & \\
\hline & $(0.003)$ & $(0.003)$ & $(0.003)$ & $(0.003)$ & & & & \\
\hline Parents' vocat. dgr. NA & 0.067 & 0.068 & 0.067 & 0.067 & & & & \\
\hline & $(0.065)$ & $(0.065)$ & $(0.065)$ & $(0.065)$ & & & & \\
\hline $\mathrm{HH}$ unemp. benefits & 0.005 * & 0.005 * & 0.005 * & 0.005 * & $0.003 * \star$ & 0.002 ** & 0.003 ** & 0.002 ** \\
\hline & $(0.003)$ & $(0.003)$ & $(0.003)$ & $(0.003)$ & $(0.001)$ & $(0.001)$ & $(0.001)$ & $(0.001)$ \\
\hline $\mathrm{HH}$ net income pc/1000 & $-0.005 * * *$ & -0.011 & $-0.005 * * *$ & -0.004 & $-0.004 * * *$ & $-0.018 * * *$ & $-0.004 * * \star$ & $-0.021 * * *$ \\
\hline & $(0.002)$ & $(0.013)$ & $(0.002)$ & $(0.022)$ & $(0.000)$ & $(0.003)$ & $(0.000)$ & $(0.005)$ \\
\hline Migrant 1st gen. & 0.007 & 0.007 & 0.007 & 0.007 & $0.015 * \star \star$ & $0.015 * * *$ & $0.015 * \star \star$ & $0.015 * * *$ \\
\hline & $(0.005)$ & $(0.005)$ & $(0.005)$ & $(0.005)$ & $(0.003)$ & $(0.003)$ & (0.003) & (0.003) \\
\hline Year Fixed Effects & yes & yes & yes & yes & yes & yes & yes & yes \\
\hline Constant & 0.009 & 0.013 & 0.006 & 0.006 & $0.013 * \star \star$ & $0.024 * * \star$ & $0.014^{* * \star}$ & $0.027 * * *$ \\
\hline & $(0.016)$ & $(0.021)$ & $(0.019)$ & $(0.029)$ & $(0.003)$ & $(0.004)$ & $(0.004)$ & $(0.007)$ \\
\hline $\bar{N}$ & 10,359 & 10,359 & 10,359 & 10,359 & 86,312 & 86,312 & 86,312 & 86,312 \\
\hline
\end{tabular}


Table 7 Fertility Trends in East and West Germany

\subsection{West Germany}

\begin{tabular}{|c|c|c|c|c|c|c|c|c|}
\hline 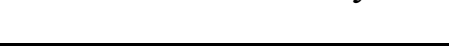 & 1 & 2 & 3 & 4 & 5 & 6 & 7 & 8 \\
\hline \multirow[t]{2}{*}{ Trend } & .0 .005 & -0.005 & -0.000 & -0.003 & 0.000 & 0.007 & 0.003 & 0.012 * \\
\hline & $(0.006)$ & $(0.006)$ & $(0.006)$ & $(0.006)$ & $(0.006)$ & $(0.007)$ & $(0.006)$ & $(0.007)$ \\
\hline Age & - & yes & - & - & - & - & yes & yes \\
\hline Education & - & - & yes & - & - & - & yes & yes \\
\hline Hh unemployment, income & - & - & - & yes & - & - & yes & yes \\
\hline Migrant 1st gen. & - & - & - & - & yes & - & yes & yes \\
\hline Aggr. unemp., growth, inequal. & - & - & - & - & - & yes & - & yes \\
\hline Constant & yes & yes & yes & yes & yes & yes & yes & yes \\
\hline
\end{tabular}

\subsection{East Germany}

\begin{tabular}{|c|c|c|c|c|c|c|c|c|}
\hline & 1 & 2 & 3 & 4 & 5 & 6 & 7 & 8 \\
\hline Trend & $\begin{array}{r}0.032 \\
(0.011)\end{array}$ & $\begin{array}{c}\text { *** } 0.028 \text { ** } \\
(0.011)\end{array}$ & $\begin{array}{r}0.027 \\
(0.011)\end{array}$ & * $\begin{array}{r}0.032 \\
(0.011)\end{array}$ & $\begin{array}{r}0.033 \\
(0.011)\end{array}$ & $\begin{array}{c}\text { ** } 0.028 \text { * } \\
(0.016)\end{array}$ & $\begin{array}{r}0.025 \\
(0.011)\end{array}$ & $\begin{array}{r}0.020 \\
(0.016)\end{array}$ \\
\hline Age & - & yes & - & - & - & - & yes & yes \\
\hline Education & - & - & yes & - & - & - & yes & yes \\
\hline Hh unemployment, income & - & - & - & yes & - & - & yes & yes \\
\hline Migrant 1st gen. & - & - & - & - & yes & - & yes & yes \\
\hline Aggr. unemp., growth, inequal. & - & - & - & - & - & yes & - & yes \\
\hline Constant & yes & yes & yes & yes & yes & yes & yes & yes \\
\hline
\end{tabular}

Note: The estimations for West Germany use 67,462 and those for East Germany use 18,850 observations, which is identical to the pooled Mikrozensus sample used in Tables 4-6. The variable "trend" is coded as calendar year/100. *,**, and *** indicate statistical significance at the 10,5 , and 1 percent level. 
Appendix

Table A.1 Descriptive statistics SOEP

\begin{tabular}{lrrrl} 
& No Teen & Birth & \multicolumn{2}{c}{ Teen } \\
& Mean & SD & Mean & SD Diff \\
\hline Teenage birth (0/1) & 0.00 & 0.00 & 1.00 & 0.00 \\
Age 16 (0/1) (ref.) & 0.24 & 0.43 & 0.06 & $0.24 * * *$ \\
Age 17 (0/1) & 0.26 & 0.44 & 0.10 & $0.30 * * *$ \\
Age 18 (0/1) & 0.26 & 0.44 & 0.30 & 0.46 \\
Age 19 (0/1) & 0.25 & 0.43 & 0.54 & $0.50 * * *$ \\
\hline [t-1]In school (0/1) & 0.78 & 0.41 & 0.35 & $0.48 * * *$ \\
[t-1]No school degree (0/1) & 0.01 & 0.08 & 0.05 & $0.23 * * *$ \\
[t-1]Lower sec. (0/1) (ref.) & 0.08 & 0.27 & 0.24 & $0.43 * * *$ \\
[t-1]Secondary (0/1) & 0.10 & 0.31 & 0.12 & 0.33 \\
[t-1]Upper sec. (0/1) & 0.00 & 0.06 & 0.00 & 0.00 \\
[t-1]Vocat. degree (0/1) (SOEP) & 0.14 & 0.35 & 0.28 & $0.45 * * *$ \\
[t-1]School dgr. NA (0/1) & 0.02 & 0.15 & 0.23 & $0.43 * * *$ \\
\hline Parents no school dgr. (0/1) & 0.03 & 0.17 & 0.11 & $0.32 * * *$ \\
Parents lower sec. (0/1) (ref.) & 0.34 & 0.47 & 0.45 & $0.50 * * *$ \\
Parents second. (0/1) & 0.30 & 0.46 & 0.29 & 0.45 \\
Parents upper sec. (0/1) & 0.33 & 0.47 & 0.09 & $0.28 * * *$ \\
Parents' school dgr. NA (0/1) & 0.01 & 0.09 & 0.06 & $0.24 * * *$ \\
Parents no vocat. dgr. (0/1) & 0.10 & 0.30 & 0.17 & $0.38 * * *$ \\
Parents vocat. dgr. (0/1) (ref.) & 0.62 & 0.49 & 0.59 & 0.49 \\
Parents academic (0/1) & 0.28 & 0.45 & 0.07 & $0.26 * * *$ \\
Parents' vocat. dgr. NA (0/1) & 0.01 & 0.10 & 0.16 & $0.37 * * *$ \\
\hline [t-1]HH unemp. benefits (0/1) & 0.17 & 0.37 & 0.34 & $0.47 * * *$ \\
[t-1]HH net income pc/1000 & 0.60 & 0.47 & 0.34 & $0.26 * * *$ \\
[t-1]HH net income missing (0/1) & 0.02 & 0.14 & 0.03 & 0.16 \\
\hline Migrant 1st gen. (0/1) & 0.10 & 0.30 & 0.36 & $0.48 * * *$ \\
Migrant 1st gen. Turk (0/1) & 0.03 & 0.17 & 0.24 & $0.43 * * *$ \\
Migrant 1st gen. other (0/1) & 0.07 & 0.25 & 0.12 & $0.33 * *$ \\
\hline West Germany (0/1) & 0.78 & 0.41 & 0.78 & 0.42 \\
[t-1] State unempl. rate & 0.11 & 0.04 & 0.10 & 0.05 \\
[t-1] State unempl. rate $<20$ & 0.07 & 0.03 & 0.07 & 0.03 \\
[t-1] State GDP growth & 0.02 & 0.03 & 0.03 & $0.03 * *$ \\
[t-1] State inc ineq 9010 & 3.62 & 0.51 & 3.53 & $0.49 * *$ \\
[t-1] State inc ineq 5010 & 1.86 & 0.14 & 1.84 & 0.14 \\
& & & &
\end{tabular}

Note: The two columns of descriptive statistics describe the teenage observations with and without birth in the given year. There are in total 14,046 person-year observations of which 146 (1.04 percent) are with and 13,897 without a birth. The column labeled "Diff" indicates the statistical significance of the difference between the two subsamples' means. ${ }^{* * *}, * *$, and $*$ indicate statistical significance at the 1,5 , and 10 percent level.

Source: SOEP (1984-2010) own calculations. 
Table A.2 Descriptive statistics Mikrozensus

\begin{tabular}{|c|c|c|c|c|}
\hline & \multicolumn{2}{|c|}{ No Teen Birth } & \multicolumn{2}{|c|}{ Teen Birth } \\
\hline & Mean & SD & Mean & SD Diff \\
\hline Teenage birth (0/1) & 0.00 & 0.00 & 1.00 & 0.00 \\
\hline Age $16(0 / 1)$ (ref.) & 0.24 & 0.43 & 0.04 & $0.19 * * \star$ \\
\hline Age $17(0 / 1)$ & 0.25 & 0.43 & 0.09 & $0.29 * \star \star$ \\
\hline Age $18(0 / 1)$ & 0.25 & 0.43 & 0.30 & $0.46 * *$ \\
\hline Age $19(0 / 1)$ & 0.25 & 0.44 & 0.57 & $0.50 * * *$ \\
\hline In school (0/1) & 0.56 & 0.50 & 0.09 & $0.29 * \star \star$ \\
\hline No school dgr. (0/1) & 0.01 & 0.11 & 0.16 & $0.36 * \star \star$ \\
\hline Lower sec. (0/1) (ref.) & 0.14 & 0.34 & 0.47 & $0.50 * \star \star$ \\
\hline Secondary (0/1) & 0.24 & 0.43 & 0.27 & 0.44 \\
\hline Upper sec. (0/1) & 0.05 & 0.22 & 0.02 & $0.13 * \star \star$ \\
\hline Vocat. degree (0/1) (MZ) & 0.15 & 0.36 & 0.23 & $0.42 * \star \star$ \\
\hline Vocat. dgr. NA (0/1) & 0.04 & 0.19 & 0.03 & 0.16 \\
\hline HH unemp. benefits $(0 / 1)$ & 0.10 & 0.30 & 0.20 & $0.40 * \star \star$ \\
\hline $\mathrm{HH}$ net income pc/1000 & 0.75 & 0.48 & 0.45 & $0.21 * \star *$ \\
\hline $\mathrm{HH}$ net income missing $(0 / 1)$ & 0.07 & 0.25 & 0.04 & $0.21 * *$ \\
\hline Migrant 1st gen. (0/1) & 0.05 & 0.21 & 0.24 & $0.43 * \star \star$ \\
\hline Migrant 1st gen. Turk (0/1) & 0.02 & 0.12 & 0.14 & $0.35 * \star \star$ \\
\hline Migrant 1st gen. other $(0 / 1)$ & 0.03 & 0.17 & 0.10 & $0.30 * \star \star$ \\
\hline West Germany (0/1) & 0.78 & 0.41 & 0.75 & 0.43 * \\
\hline [t-1] State unempl. rate & 0.11 & 0.04 & 0.11 & 0.04 \\
\hline [t-1] State unempl. rate $<20$ & 0.07 & 0.03 & 0.07 & 0.03 \\
\hline [t-1] State GDP growth & 0.03 & 0.03 & 0.03 & 0.04 * \\
\hline [t-1] State inc ineq 9010 & 3.66 & 0.55 & 3.58 & $0.58 * * \star$ \\
\hline [t-1] State inc ineq 5010 & 1.86 & 0.15 & 1.84 & $0.16 * \star \star$ \\
\hline
\end{tabular}

Note: The two columns of descriptive statistics describe the teenage observations with and without birth in the given year. There are in total 107,915 person-year observations of which 544 ( 0.5 percent) are with and 107,371 without a birth. The column labeled "Diff" indicates the statistical significance of the difference between the two subsamples' means. ${ }^{* * *}, * *$, and $*$ indicate statistical significance at the 1,5 , and 10 percent level.

Source: Mikrozensus (1991, 1995, 1999, 2003, 2007) and own calculations. 
Table A.3 Results - Step 2: Robustness test of aggregate determinants

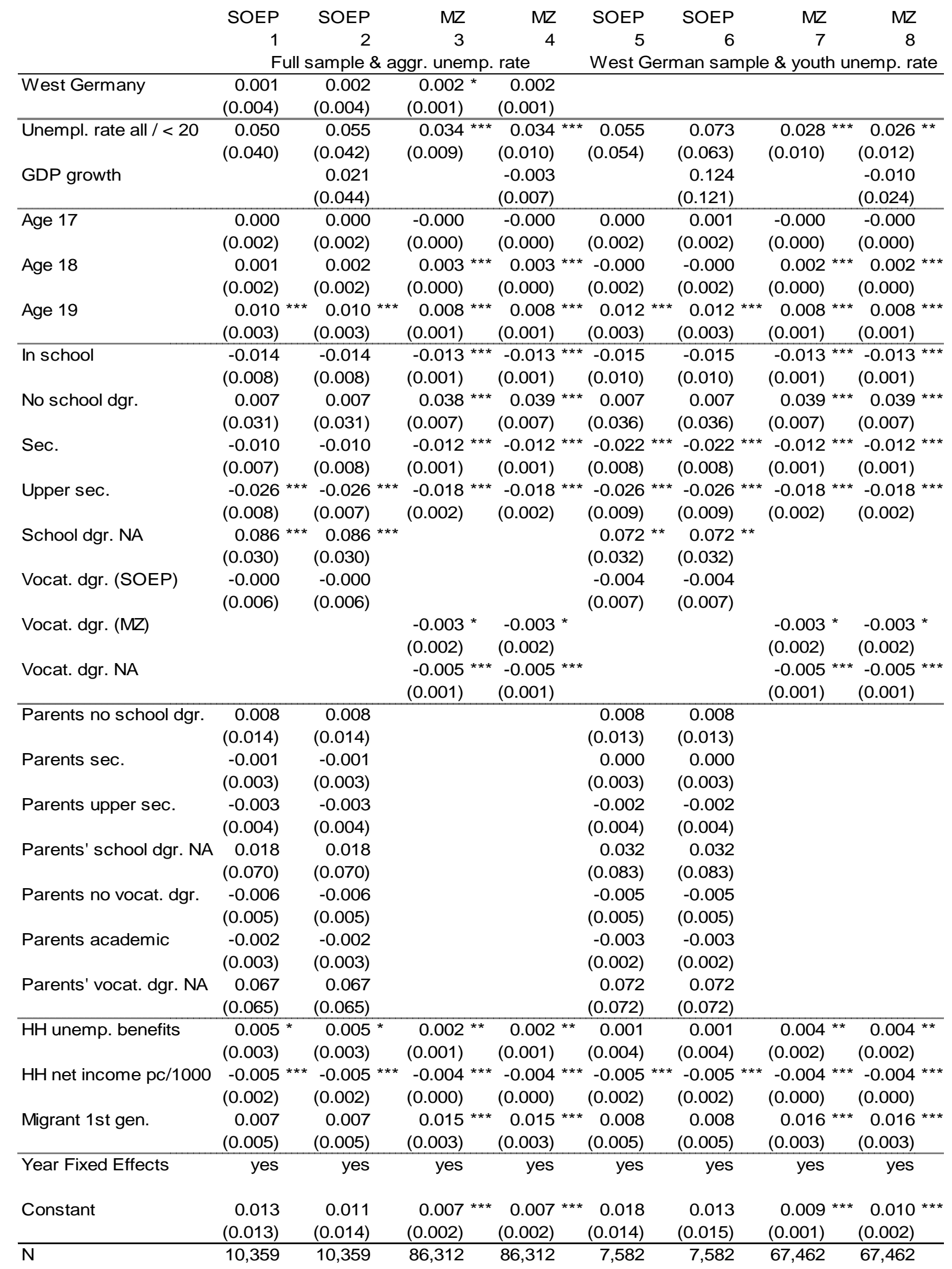

Note: $* * *$, and $* * *$ indicate statistical significance at the 10,5 , and 1 percent level. 